\title{
Bioorthogonal photocatalytic decaging-enabled mitochondrial proteomics
}

Zongyu Huang ${ }^{1 \#}$, Ziqi Liu ${ }^{1 \#}$, Xiao Xie ${ }^{1}$, Ruxin Zeng ${ }^{1}, Z_{\text {Zujie Chen }}{ }^{1}$, Linghao Kong ${ }^{2}$, Xinyuan Fan ${ }^{1 *}$, Peng R. Chen ${ }^{12^{*}}$

${ }^{1}$ Synthetic and Functional Biomolecules Center, Key Laboratory of Bioorganic Chemistry and Molecular Engineering of Ministry of Education, Beijing National Laboratory for Molecular Sciences, College of Chemistry and Molecular Engineering, Peking University, Beijing 100871, China.

${ }^{2}$ Peking-Tsinghua Center for Life Sciences, Peking University, Beijing 100871, China.

\section{Table of Contents}

\section{$>$ Material and Methods}

\section{Biology}

General considerations

Cell culture

Immunoblotting

Photo-cytotoxicity study of iridium catalysts

Live-cell imaging of localization of Ir8 in mitochondria

Flowcytometry analysis of cellular uptake of Ir8

Photocatalytic decaging of PAB-rhodamine in mitochondria

Photocatalytic proximity labeling in mitochondria

Photocatalytic proximity labeling in mitochondria for LC-MS/MS analysis

\section{Chemistry}

General considerations

Synthesis of PAB-caged QM probe

Synthesis of PAB-caged rhodamine probe

Photocatalyst screening

HPLC analysis of photocatalytic decaging of PAB-QM-Bio

Photocatalytic decaging of PAB-QM-Bio for BSA labeling

\section{$>$ Supporting Figures 1-8}

\section{$>$ References}

$>\quad$ NMR spectra 


\section{MATERIALS AND METHODS}

\section{Biology}

\section{General considerations}

Media, buffer components, kits, and cloning enzymes were used as received from the specified commercial suppliers. All expression media, buffers and antibiotics were prepared using purified $\mathrm{H}_{2} \mathrm{O}$ (Mili-Q Reference) and autoclaved or filter-sterilized, as appropriate.

Images of protein gels including Coomassie SDS-PAGE gel and immunoblotting membranes were taken on ChemiDoc XRS+ (Bio-Rad). Fluorescence imaging of SDS-PAGE gel was performed on Typhoon FLA 9500 (GE healthcare). Luminescence and light absorbance of cell samples were measured on a Synergy H4 microplate reader (Bio-Tek). If not specifically mentioned, confocal microscopy images were obtained on LSM 700 laser scanning confocal microscope (Zeiss). Flowcytometry was performed on LSRFortessa cell analyzer (BD biosciences) supplemented with BD FACSDiva software. The figures were created with BioRender.com (agreement number DG23280ZRQ).

\section{Cell culture}

HEK293T, HeLa, RAW264.7 and MDA-MB-231 cells were purchased from the American Type Culture Collection (ATCC). HER2 ${ }^{+}$MDA-MB-231 stable cell line (expressing HER2-EGFP fusion) was constructed from MDA-MB-231 cells as previously reported ${ }^{1}$. All the cells were grown in DMEM (Dulbecco's modified Eagle's medium, Gibco) supplemented with $10 \%$ fetal bovine serum (FBS, Gibco) at $37{ }^{\circ} \mathrm{C}$ in $5 \% \mathrm{CO}_{2}$.

\section{Immunoblotting}

Gel electrophoresis was performed using tris-glycine polyacrylamide gels in a vertical electrophoresis tank (Tanon, VE-180) with a PowerPac Basic Power Supply (Bio-Rad). After electrophoresis, gels were transferred to PVDF membranes (Millipore) using a gel transfer device (Tanon, VE-186), and washed with PBST (0.01 M PBS pH 7.4, with 0.1\% Tween 20). All wash and incubation steps were performed on an orbital shaker at room temperature. After blocked with $5 \%$ bovine serum albumin (BSA) in PBST for 1 hour, membranes were washed (5 min) for 3 rounds with PBST, and incubated with primary antibodies diluted in PBST for 1 hour, followed by 3 rounds of wash (5 min) with PBST. Membranes were then incubated with horseradish peroxidase (HRP)conjugated secondary antibodies diluted in PBST for 1 hour, followed by 3 rounds of wash ( $5 \mathrm{~min}$ ) with PBST. Immobilon Western Chemiluminescent HRP Substrate (Millipore) and ChemiDoc XRS+ (Bio-Rad) were used for chemiluminescence development and detection.

\section{Photo-cytotoxicity study of iridium catalysts}

HeLa cells were seeded in a 96-well clear cell culturing plate (Corning) at a density of 5,000 cells per well and incubated at $37^{\circ} \mathrm{C}$ with $5 \% \mathrm{CO}_{2}$ for $24 \mathrm{~h}$ before treatment. The culture medium was then replaced by $100 \mu \mathrm{L}$ fresh DMEM (with $10 \%$ FBS) containing photocatalyst Ir8 $(0.1,0.2,0.3$, 
$0.5,0.6,0.8,0.9,1.0,2.0,5.0,10.0 \mu \mathrm{M}$ ) with $0.1 \% \mathrm{v} / \mathrm{v}$ DMSO with $0.5 \% \mathrm{v} / \mathrm{v}$ DMSO. Samples without photocatalyst were used as controls. For the cellular uptake of photocatalyst, all the samples were incubated at $37^{\circ} \mathrm{C}$ with $5 \% \mathrm{CO}_{2}$ for $30 \mathrm{~min}$ in the dark. After incubation, the culture medium was refreshed with $100 \mu \mathrm{L}$ DMEM (with $10 \%$ FBS) and the cells were irradiated by mild blue LED for $15 \mathrm{~min}$ at room temperature. Then the cells were incubated at $37^{\circ} \mathrm{C}$ with $5 \% \mathrm{CO}_{2}$ for $48 \mathrm{~h}$ before analysis. The MTS assay was carried out using CellTiter 96 Aqueous One Solution kit (Promega, G3581) according the manufacture's protocol with minor modifications. In brief, $10 \mu \mathrm{L}$ of One Solution Reagent was added into each well of 96-well assay plate containing $100 \mu \mathrm{L}$ culture medium, and the plate was incubated at $37^{\circ} \mathrm{C}$ with $5 \% \mathrm{CO}_{2}$ for $1 \mathrm{~h}$. The absorbance at $490 \mathrm{~nm}$ of each well was recorded on a Synergy $\mathrm{H} 4$ microplate reader (Bio-Tek). All the proliferation data were normalized to the DMSO control (100\%). GraphPad Prism 8.0 software was used to create the graphs and calculate the IC50 value by four-parameters non-linear fit.

\section{Live-cell imaging of localization of Ir8 in mitochondria}

Approximately 10,000 cells (HeLa, RAW264.7, HEK293T or MDA-MB-231) were seeded in a LabTek-II 8-well glass chamber with $200 \mu \mathrm{L}$ cell culture medium, and incubated at $37^{\circ} \mathrm{C}$ with $5 \%$ $\mathrm{CO}_{2}$ for 24-48 $\mathrm{h}$. The medium was removed and the cells were rinsed with PBS. Ir8 $(1 \mu \mathrm{M})$ was combined with MitoTracker ${ }^{\mathrm{TM}}$ Deep Red $(0.1 \mu \mathrm{M}$, Thermo) in $100 \mu \mathrm{L}$ DMEM and the cells were incubated with the mixture for $30 \mathrm{~min}$ at $37^{\circ} \mathrm{C}$. The cells were finally washed with PBS three times before immediate microscopic analysis on an LSM 700 laser scanning confocal microscope (Zeiss). The fluorescent images were captured in Hoechst channel $\left(\lambda_{\mathrm{ex}}=405 \mathrm{~nm}\right)$ for photocatalyst luminescence and Cy 5 channel $\left(\lambda_{\mathrm{ex}}=639 \mathrm{~nm}\right)$ for MitoTracker. Processing of images were carried out using ZEN 3.2 blue edition (ZEISS). Pearson's R values for colocalization were calculated using Coloc2 tool embedded in Fiji-Image J (v1.53k).

\section{Flowcytometry analysis of cellular uptake of Ir8}

Approximately $2 \times 10^{5}$ of annotated cells were added to a well in V-bottom 96 -well clear microplate. The cells were pelleted by centrifugation $(700 \mathrm{~g}, 4 \mathrm{~min})$, and incubated with $500 \mathrm{nM}$ photocatalyst Ir8 in $200 \mu \mathrm{L}$ fresh culturing media (with 10\% FBS) at room temperature for 20-30 min. Samples without photocatalyst were used as blank controls. After incubation, the cells were pelleted, resuspended in $200 \mu \mathrm{L}$ PBS, and directly analyzed by flowcytometry (BD LSRFortessa cell analyzer). The iridium luminescence was detected using AmCyan channel $\left(\lambda_{\mathrm{ex}}=405 \mathrm{~nm}, 525 / 50\right.$ nm filter). Data was analyzed using FlowJo v10 (FlowJo, LLC).

\section{Photocatalytic decaging of PAB-rhodamine in mitochondria}

For live-cell imaging, $\sim 10,000 \mathrm{HeLa}$ cells were seeded in a LabTek-II 8-well glass chamber with $200 \mu \mathrm{L}$ cell culture medium, and were incubated at $37{ }^{\circ} \mathrm{C}$ with $5 \% \mathrm{CO}_{2}$ for $24-48 \mathrm{~h}$. The medium was removed and the cells were rinsed with PBS. MitoTracker ${ }^{\mathrm{TM}}$ Deep Red $(0.1 \mu \mathrm{M}$, Thermo) was combined with or without Ir8 $(200 \mathrm{nM})$ in DMEM, and the cells were incubated with the mixture for 30 min at $37^{\circ} \mathrm{C}$. The cells were then washed twice with PBS and incubated with PAB-rhodamine (50 $\mu \mathrm{M}$ in DMEM) for $30 \mathrm{~min}$ followed by mild blue LED irradiation $\left(4 \mathrm{~mW} / \mathrm{cm}^{2}, 15 \mathrm{~min}\right)$. The samples were finally washed with PBS three times before microscopy analysis on an LSM 700 laser scanning confocal microscope (Zeiss). The fluorescent images were captured in Rho110 channel 
$\left(\lambda_{\text {ex }}=488 \mathrm{~nm}\right)$ and Cy5 channel $\left(\lambda_{\text {ex }}=639 \mathrm{~nm}\right)$. Processing of images were carried out using ZEN 3.2 blue edition (ZEISS).

For flowcytometry analysis, $\sim 2 \times 10^{5} \mathrm{HeLa}$ cells were added to a well in V-bottom 96-well clear microplate with 100-200 $\mu \mathrm{L}$ cell culture medium. The cells were pelleted by centrifugation $(500 \mathrm{~g}$, $5 \mathrm{~min})$, and incubated with $\operatorname{Ir} 8(200 \mathrm{nM})$ in DMEM $(200 \mu \mathrm{L})$ for $30 \mathrm{~min}$ at $37{ }^{\circ} \mathrm{C}$ with $5 \% \mathrm{CO}_{2}$ followed by 2 rounds of wash with $200 \mu \mathrm{L}$ PBS. The cells were then incubated with PAB-rhodamine (50 $\mu \mathrm{M}$ in DMEM) for $30 \mathrm{~min}$ followed by mild blue LED irradiation ( $15 \mathrm{~min}$ ). The samples were then washed with PBS twice and finally analyzed on BD LSRFortessa cell analyzer. Data was analyzed using FlowJo v10 (FlowJo, LLC). Samples without Ir8 incubation or without LED irradiation were used as controls.

\section{Photocatalytic proximity labeling in mitochondria}

For immunoblotting analysis, cells (HeLa or RAW264.7) were cultured to $>90 \%$ confluence in 6well plate. After removal of culture medium and wash with PBS ( $1 \mathrm{~mL}$ per well), the cells were incubated with $\operatorname{Ir8}\left(0,100,200 \mathrm{nM}\right.$ in $1 \mathrm{~mL}$ DMEM) for $30 \mathrm{~min}$ at $37^{\circ} \mathrm{C}$ with $5 \% \mathrm{CO}_{2}$, followed by 2 rounds of wash with PBS. Then PAB-QM-Bio (100 $\mu \mathrm{M}$ in $1 \mathrm{~mL}$ DMEM) was added and the cells were incubated for $30 \mathrm{~min}$ at $37{ }^{\circ} \mathrm{C}$ with $5 \% \mathrm{CO}_{2}$, followed by mild blue LED irradiation $\left(4 \mathrm{~mW} / \mathrm{cm}^{2}\right.$, 0-15 $\mathrm{min}$ ) at room temperature and placed in the dark for $15 \mathrm{~min}$ at $37^{\circ} \mathrm{C}$. After washed once with PBS ( $1 \mathrm{~mL}$ per well), the cells were harvested using $0.25 \%$ trypsin-EDTA (Gibco), resuspended in fresh medium $(1 \mathrm{~mL})$, and transferred to a $1.5-\mathrm{mL}$ tube placed on ice. The cells were pelleted by centrifugation $\left(850 \mathrm{~g}, 3 \mathrm{~min}, 4{ }^{\circ} \mathrm{C}\right.$ ), resuspended in $100 \mu \mathrm{L}$ RIPA strong lysis buffer (CWBIO) and incubated on ice for $10 \mathrm{~min} .25 \mu \mathrm{L} 5 \mathrm{X}$ SDS-PAGE reducing loading buffer (CWBIO) was added to the lysate (final concentration of loading buffer was $1 \mathrm{X}$ ), and the samples were heated at $95^{\circ} \mathrm{C}$ for 15 min. Immunoblotting was performed with $4-15 \%$ gradient SDS-PAGE and $0.45 \mu \mathrm{m}$ PVDF membrane according to the general protocol described above. Mouse anti-biotin mAb (Santa Cruz, sc-101339) and rabbit $\alpha$-tubulin mAb (Cell Signaling Technology, 2125S) were used as primary antibodies (1:1,000 dilution), while HRP-linked anti-mouse IgG (Cell Signaling Technology, 7076S) and HRP-linked anti-rabbit IgG (Cell Signaling Technology, 7074S) were used as secondary antibodies (1: 5,000 dilution).

For immunofluorescent imaging, HeLa cells were cultured in a LabTek-II 8-well glass chamber to $40 \sim 80 \%$ confluence, and subjected to photocatalytic proximity labeling as described above. Upon completion of blue LED irradiation ( $4 \mathrm{~mW} / \mathrm{cm}^{2}, 15 \mathrm{~min}$ ), cells were washed with PBS (200 $\mu \mathrm{L}$ per well for three times, the same below), and fixed with $4 \%$ formaldehyde for $15 \mathrm{~min}$ at room temperature. Cells were then permeabilized with $0.2 \%$ Triton-X100 and blocked by $3 \%$ BSA. Next, the cells were incubated with primary antibody anti-TOMM20 (Proteintech, 1:300) overnight at $4{ }^{\circ} \mathrm{C}$, followed by incubation with fluorescent antibodies anti-Rabbit-DyLight633 and streptavidinAlexaFluro488 for $1 \mathrm{~h}$ at room temperature. All the reagents and antibodies were dissolved in PBS and the cells were washed with PBS between each step. Images of stained samples were visualized on LSM 700 laser scanning confocal microscope (Zeiss) and processed using ZEN 3.2 blue edition (ZEISS). 


\section{Photocatalytic proximity labeling in mitochondria for LC-MS/MS analysis}

\section{Mitochondrial biotinylation}

HeLa cells or RAW264.7 cells cultured $>95 \%$ confluence in a 10-cm culturing dish (Corning) were used. The culture medium was removed and the cells were washed with $10 \mathrm{~mL}$ PBS. The cells were then incubated with or without Ir8 (100 nM in $10 \mathrm{~mL} \mathrm{DMEM)} \mathrm{for} 30 \mathrm{~min}$ at $37{ }^{\circ} \mathrm{C}$ with $5 \% \mathrm{CO}_{2}$ followed by 2 rounds of wash with PBS. Then PAB-QM-Bio (100 $\mu \mathrm{M}$ in $10 \mathrm{~mL}$ DMEM) was added and the cells were incubated with PAB-QM-Bio for $30 \mathrm{~min}$ at $37^{\circ} \mathrm{C}$ with $5 \% \mathrm{CO}_{2}$. The cells were irradiated by mild blue LED for $15 \mathrm{~min}$ at room temperature and placed in the dark for $15 \mathrm{~min}$ at $37{ }^{\circ} \mathrm{C}$ with $5 \% \mathrm{CO}_{2}$. After washed once with PBS, the cells were harvested using $0.25 \%$ trypsinEDTA (Gibco), resuspended in fresh medium $(10 \mathrm{~mL})$, and transferred to a $15-\mathrm{mL}$ tube (Corning) placed on ice. The cells were pelleted by centrifugation $\left(850 \mathrm{~g}, 3 \mathrm{~min}, 4^{\circ} \mathrm{C}\right)$ and stored at $-80{ }^{\circ} \mathrm{C}$ overnight.

\section{Cell lysis and streptavidin enrichment}

Each cell pellet was lysed by resuspension in $500 \mu \mathrm{L}$ RIPA strong lysis buffer $(\mathrm{pH} 7.4$, with $1 \%$ Triton X-100, $50 \mathrm{mM}$ Tris, $150 \mathrm{mM} \mathrm{NaCl}$, 1\% sodium deoxycholate, etc.) (CWBIO, CW2333S) supplemented with 1X protease inhibitor cocktail (Bimake, B14001) and $1 \mathrm{mM}$ PMSF on ice. The sample was sonicated to generate a clear lysate using Vibra Cell VCX Processor (SONICS). A tiny fraction of the lysate was used for BCA analysis against BSA standards. Then the protein was precipitated by the addition of $\mathrm{MeOH} / \mathrm{CHCl}_{3}$ followed by centrifugation $\left(10,000 \mathrm{~g}, 20 \mathrm{~min}, 4^{\circ} \mathrm{C}\right)$, and washed three times with ice-cold methanol. For each lysate sample, $\sim 2.5 \mathrm{mg}$ of total protein was precipitated and redissolved in PBS containing $2 \%$ SDS. The sample was then transferred to a $15-\mathrm{mL}$ centrifuge tube (Corning) and diluted with PBS to the point that the final concentration of SDS was $0.2 \%$. High-capacity streptavidin resin beads (Thermo, 20357) were equilibrated by washing three times with PBS. For each sample in 15-mL tube, $100 \mu \mathrm{L}$ of bead slurry was added and incubated for 3 hours at room temperature with gentle rotation. After the incubation, the beads were pelleted by centrifugation $(1,400 \mathrm{~g}, 3 \mathrm{~min})$, resuspended in PBS with $0.2 \% \mathrm{SDS}$, and incubated at room temperature for $10 \mathrm{~min}$. The beads were then washed with $5 \mathrm{~mL}$ PBS for 6 times.

As quality control measure, a small fraction ( $10 \%)$ of protein-bound streptavidin beads were taken. The beads were pelleted and boiled at $95^{\circ} \mathrm{C}$ for $30 \mathrm{~min}$ in $50 \mu \mathrm{L}$ of $2 \mathrm{X}$ SDS-PAGE reducing loading buffer supplemented with $2 \mathrm{mM}$ biotin. Immunoblotting was performed with $4-15 \%$ gradient SDSPAGE and $0.45 \mu \mathrm{m}$ PVDF membrane according to the general protocol described above. Mouse anti-biotin mAb (Santa Cruz, sc-101339) and HRP-linked anti-mouse IgG (Cell Signaling Technology, 7076S) were used as primary and secondary antibodies, respectively.

\section{On-bead digestion and dimethyl labeling}

The protein-bound streptavidin beads were pelleted by centrifugation $(1,400 \mathrm{~g}, 3 \mathrm{~min})$ and the supernatant was removed, followed by the addition of $500 \mu \mathrm{L} 6 \mathrm{M}$ urea in PBS and $25 \mu \mathrm{L} 200 \mathrm{mM}$ DTT. The beads were resuspended by vortexing, and incubated at $37{ }^{\circ} \mathrm{C}$ for $30 \mathrm{~min}$ in a ThermoMixer (Eppendorf). $25 \mu \mathrm{L}$ of $400 \mathrm{mM}$ iodoacetamide (IAA) was then added, and the resulting mixture was incubated again at $37^{\circ} \mathrm{C}$ for $30 \mathrm{~min}$ in the dark. After incubation, the beads were washed with $0.1 \mathrm{M}$ trimethylammonium bicarbonate (TEAB) buffer ( $1 \mathrm{~mL}$, four times) and 
pelleted. $100 \mu \mathrm{L} 0.1 \mathrm{M} \mathrm{TEAB}$ buffer and $1 \mu \mathrm{g}$ trypsin were then added, and the beads were incubated at $37^{\circ} \mathrm{C}$ for $16 \mathrm{~h}$ in a ThermoMixer to digest the proteins.

To each $100 \mu \mathrm{L}$ of the digested peptides in $0.1 \mathrm{M} \mathrm{TEAB}$ buffer were added $4 \mu \mathrm{L}$ of $0.6 \mathrm{M} \mathrm{NaBH}_{3} \mathrm{CN}$ and $4 \mu \mathrm{L}$ of $4 \%$ (v/v) stable isotopic formaldehyde $\left(\mathrm{CH}_{2} \mathrm{O}\right.$ or $\left.{ }^{13} \mathrm{CD}_{2} \mathrm{O}\right)$. The resulting mixture was vortexed immediately, and incubated at room temperature for $30 \mathrm{~min}$. After incubation, $16 \mu \mathrm{L}$ of $1 \%$ (v/v) ammonia was added to quench the reaction, followed by the addition of $8 \mu \mathrm{L}$ formic acid. After vortexing, heavy $\left({ }^{13} \mathrm{CD}_{2} \mathrm{O}\right)$ - and light $\left(\mathrm{CH}_{2} \mathrm{O}\right)$-labeled samples were combined at a ratio of 1:1 $(\mathrm{v} / \mathrm{v})$ to generate duplex dimethyl-labeled samples, which were further desalted on $\mathrm{C} 18$ tips (Thermo, 87784) according to the manufacture's protocol and evaporated to dryness in a vacuum concentrator.

Liquid chromatography and mass spectrometry

Desalted, dimethyl-labeled peptides were analyzed on a LTQ Orbitrap Elite System (Thermo) coupled to an Easy-nLC HPLC system (Thermo). The HPLC solvent A was $0.1 \%$ formic acid (FA) in $\mathrm{H}_{2} \mathrm{O}$, and the solvent $\mathrm{B}$ was $0.1 \% \mathrm{FA}$ in $\mathrm{MeCN}$. The samples were run using a 180 -min gradient method (0 min 2\% B; 1 min 2\% B; 2 min 5\% B; $182 \min 35 \%$ B; $186 \min 75 \%$ B; $196 \min 75 \%$ ) with a flow rate of $300 \mathrm{~nL} /$ minute. The MS1 analysis was performed under the positive-ion mode with a full-scan $\mathrm{m} / \mathrm{z}$ range from 300.00 to $1,600.00$ and a mass resolution of 120,000 . MS/MS fragmentation was performed in the data-dependent mode using the collision mode of CID, acquiring MS2 scans after each MS1 scan on the top 15 most abundant ions. The minimum signal threshold was set to 5,000 counts; the CID-normalized collision energy was set to 35; the isolation width $(\mathrm{m} / \mathrm{z})$ was set to 2.0 ; the default charge state was +2 ; the activation $\mathrm{Q}$ was set to 0.250 and the activation time was set to $10.00 \mathrm{~ms}$. Charge rejection was enabled for charge states that were unassigned and 1. Dynamic exclusion time was set to $20.0 \mathrm{~s}$.

\section{Analysis of proteomic data}

All MS data were interpreted using MaxQuant v1.6.10 software (three biologically independent samples for HeLa cells and three for RAW264.7 cells). The quantification of light/heavy ratios was calculated with precursor mass tolerance of $20 \mathrm{ppm}$. For protein ID identification, MS/MS spectra were searched against UniProt databases (20,379 human proteins for HeLa cells and 17,068 mouse proteins for RAW264.7 cells). Half-tryptic termini and up to 2 missing trypsin cleavages were allowed. Carbamidomethylation at cysteine $(+57.0215 \mathrm{Da})$ and isotopic modifications $(+28.0313$ and $+34.0631 \mathrm{Da}$ for light and heavy labeling, respectively) at lysine/N-terminal were set as fixed modifications. Oxidation at methionine (+15.9949 Da) and acetylation of N-terminal (+42.0106 Da) were set as variable modifications. Each of three biologically independent samples was analyzed separately. Contaminants and proteins identified as reverse hits were removed.

\section{$\underline{\text { LPS stimulation }}$}

RAW264.7 cells were cultured to $>80 \%$ confluence, and the culture medium was replaced by DMEM with or without LPS (200 ng/mL), followed by incubation at $37{ }^{\circ} \mathrm{C}$ with $5 \% \mathrm{CO}_{2}$ for $8 \mathrm{~h}$. For Immunoblotting analysis, cells were harvested using cold PBS and transferred to $1.5-\mathrm{mL}$ tubes. 5X SDS-PAGE reducing loading buffer was added to the samples (the final concentration of loading buffer was $2 \mathrm{X}$ ), and the resulting mixture was heated at $95^{\circ} \mathrm{C}$ for $30 \mathrm{~min}$ to lyse the cells. For every $10^{6}$ cells, $\sim 100 \mu \mathrm{L}$ lysate was prepared. Immunoblotting analysis was performed with $4-15 \%$ 
gradient SDS-PAGE according to the general protocol described above. Rabbit anti-SODM mAb (Abcam, ab68155,), rabbit anti-IRG1 mAb (Abcam, ab222411), mouse anti-Aconitase $2 \mathrm{mAb}$ (Abcam, ab110321), mouse anti-NLRP3 mAb (Adipogen, AG-20B-0014) and rabbit anti $\alpha$-tubulin $\mathrm{mAb}$ (Cell Signaling Technology, 2125S) were used as primary antibodies (1:1,000 dilution), while HRP-linked anti-mouse IgG (Cell Signaling Technology, 7076S) and HRP-linked anti-rabbit IgG (Cell Signaling Technology, 7074S) were used as secondary antibodies (1: 5,000 dilution).

For LC-MS/MS analysis, RAW 264.7 cells cultured in 10-cm dish (Corning) was stimulated with $200 \mathrm{ng} / \mathrm{mL}$ LPS as described above, and subjected to mitochondrial proximity labeling according to the established protocol (see "Photocatalytic proximity labeling in mitochondria for LC-MS/MS analysis"). Sample without LPS stimulation and sample without iridium catalyst were used as controls. For dimethyl labeling, the three samples (experimental group and two controls) were subjected to triplex stable isotopic labeling to yield heavy $\left({ }^{13} \mathrm{CD}_{2} \mathrm{O}\right.$ and $\mathrm{NaBD}_{3} \mathrm{CN}$, for $+\mathrm{LPS} /+\mathbf{I r 8}$ sample), medium $\left(\mathrm{CD}_{2} \mathrm{O}\right.$ and $\mathrm{NaBH}_{3} \mathrm{CN}$, for $-\mathrm{LPS} /+\mathrm{Ir8}$ sample) and light $\left(\mathrm{CH}_{2} \mathrm{O}\right.$ and $\mathrm{NaBH}_{3} \mathrm{CN}$, + LPS/-Ir8 sample)-labeled samples, which were combined at a ratio of 1:1:1 $(\mathrm{v} / \mathrm{v} / \mathrm{v})$ to generate triplex dimethyl-labeled samples for quantitative LC-MS/MS analysis. For data analysis, the quantification of light/heavy, light/medium or medium/heavy ratios was calculated with precursor mass tolerance of $20 \mathrm{ppm}$. Carbamidomethylation at cysteine $(+57.0215 \mathrm{Da})$ and isotopic modifications $(+28.0313,+32.0564$ and $+36.0757 \mathrm{Da}$ for light, medium and heavy labeling, respectively) at lysine/ $\mathrm{N}$-terminal were set as fixed modifications. Oxidation at methionine $(+15.9949 \mathrm{Da})$ and acetylation of N-terminal $(+42.0106 \mathrm{Da})$ were set as variable modifications. Proteins with heavy/light ratio $<1.6$ were filtered out to retain significantly labeled proteome. Each of three biologically independent replicate was analyzed separately. Contaminants and proteins identified as reverse hits were removed. 


\section{Chemistry}

\section{General considerations}

All chemical reagents are in analytical grade, obtained from commercial suppliers, and used without further purification. All the photocatalysts were commercially purchased from J\&K Scientific ${ }^{\circledR}$ or Energy Chemical ${ }^{\circledR}$. Reactions were monitored by thin layer chromatography (TLC) carried out on $0.25 \mathrm{~mm}$ silica plates (Wish Chemical, Yantai, China), using UV light as the visualizing agent and an ethanolic solution of ammonium molybdate and heat, or ninhydrin and heat as developing agents. Preparative TLC was carried out on $0.5 \mathrm{~mm}$ silica plates (Wish Chemical, Yantai, China). If not specially mentioned, flash column chromatography uses silica gel (200-300 mesh) supplied by Tsingtao Haiyang Chemicals (China).

Chromatographic analysis was performed using 1260 infinity II analytical HPLC system (Agilent) equipped with a Poroshell 120 EC-C18 column $(2.7 \mu \mathrm{m}, 3.0 \times 150 \mathrm{~mm})$. UPLC-MS analysis was performed on an ACQUITY UPLC I-Class SQD 2(Waters) system equipped with electrospray ionization (ESI) and a BEH C18 Acquity column $(1.7 \mu \mathrm{m}, 2.1 \times 50 \mathrm{~mm})$. High resolution mass spectra (HRMS) were recorded on a Fourier Transform Ion Cyclotron Resonance Mass Spectrometer (Solarix XR, Bruker).

NMR spectra were recorded on Bruker-500 MHz NMR (AVANCE III), Bruker-400 MHz NMR (AVANCE III) or Bruker-600 $\mathrm{MHz}$ (AVANCE Neo) spectrometers and evaluated using MestReNova (Mestrelab Research) software. TMS was used as internal standard for ${ }^{1} \mathrm{H}$ NMR $(0.00$ ppm), and solvent signal was used as reference for ${ }^{1} \mathrm{H} \mathrm{NMR}\left(\mathrm{CDCl}_{3}, 7.26 \mathrm{ppm}\right),{ }^{13} \mathrm{C} \mathrm{NMR}\left(\mathrm{CDCl}_{3}\right.$, $77.16 \mathrm{ppm}$ ). The following abbreviations were used to explain the multiplicities: $\mathrm{s}=$ singlet, $\mathrm{d}=$ doublet, $\mathrm{t}=$ triplet, $\mathrm{q}=$ quartet, $\mathrm{m}=$ multiplet, $\mathrm{br}=$ broad .

\section{Synthesis of PAB-caged QM probe}

Methyl 4-((4-azidobenzyl)oxy)-3-formylbenzoate (5)

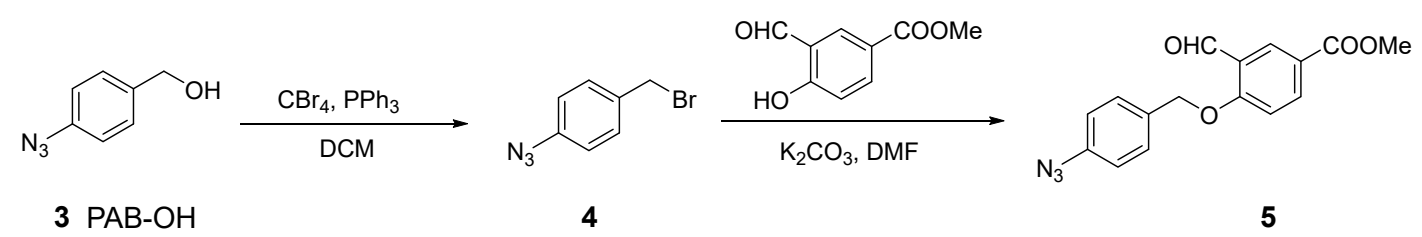

In a round-bottom flask with a stir bar, 4-azidophenylmethanol (PAB-OH, $3.0 \mathrm{~g}, 20 \mathrm{mmol}$ ) was dissolved in anhydrous DCM $(180 \mathrm{~mL})$ under $\mathrm{N}_{2}$ atmosphere. Then $\mathrm{CBr}_{4}(16.6 \mathrm{~g}, 2.5 \mathrm{eq})$ was added at $0{ }^{\circ} \mathrm{C}$, and triphenylphosphine $\left(10.5 \mathrm{~g}, 2.0\right.$ eq.) was added in small portions while stirring at $0{ }^{\circ} \mathrm{C}$. After being stirred at room temperature for $1.5 \mathrm{~h}$, the reaction was quenched by saturated $\mathrm{NH}_{4} \mathrm{Cl}$ $(150 \mathrm{~mL})$ and extracted with DCM $(100 \mathrm{~mL}$, three times). The combined organic phase was dried over $\mathrm{Na}_{2} \mathrm{SO}_{4}$ and concentrated on a rotary evaporator. The residue was purified by flash column chromatography with silica gel (elution with $\mathrm{PE} / \mathrm{EtOAc}=50 / 1$ ) to afford 1-azido-4(bromomethyl)benzene (4) as yellow liquid (2.6 g, 61\% yield).

To a stirring solution of methyl 3-formyl-4-hydroxybenzoate (1.44 g, $8 \mathrm{mmol})$ in anhydrous DMF $(16 \mathrm{~mL})$ was added $\mathrm{K}_{2} \mathrm{CO}_{3}\left(2.21 \mathrm{~g}, 2.0\right.$ eq.). The mixture was cooled to $0{ }^{\circ} \mathrm{C}$ and 1-azido-4- 
(bromomethyl)benzene (4, $1.7 \mathrm{~g}, 1.0$ eq.) was added dropwise. After being stirred at room temperature overnight, the mixture was quenched by saturated $\mathrm{NH}_{4} \mathrm{Cl}(20 \mathrm{~mL})$ and extracted with EtOAc (40 mL, three times). The combined organic phase was dried over $\mathrm{Na}_{2} \mathrm{SO}_{4}$ and concentrated on a rotary evaporator. The residue was purified by flash column chromatography with silica gel (elution with PE/EtOAc = 2/1) to afford methyl 4-((4-azidobenzyl)oxy)-3-formylbenzoate (5) as a white solid (2.3 g, 92\% yield).

${ }^{1}$ H NMR (400 MHz, Chloroform- $d$ ) $\delta 10.50(\mathrm{~s}, 1 \mathrm{H}), 8.53$ (d, $\left.J=2.3 \mathrm{~Hz}, 1 \mathrm{H}\right), 8.23$ (dd, $J=8.8$, $2.3 \mathrm{~Hz}, 1 \mathrm{H}), 7.44$ (d, $J=8.0 \mathrm{~Hz}, 2 \mathrm{H}), 7.09$ (dd, $J=8.5,5.5 \mathrm{~Hz}, 3 \mathrm{H}), 5.23$ (s, 2H), 3.91 (s, 3H).

${ }^{13}$ C NMR (101 MHz, Chloroform-d) $\delta 188.69,165.93,163.70,140.50,137.09,131.88,130.76$, $129.09,124.75,123.35,119.47,112.75,70.31,52.24$.

FT-HRMS (ESI) m/z calcd. for $\mathrm{C}_{16} \mathrm{H}_{13} \mathrm{~N}_{3} \mathrm{NaO}_{4}[\mathrm{M}+\mathrm{Na}]^{+}$: 334.0798; Found: 334.0799.

Methyl 4-((4-azidobenzyl)oxy)-3-(difluoromethyl)benzoate (6)
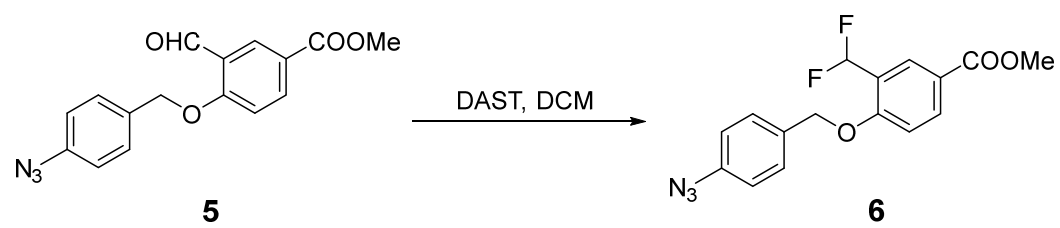

In a dried round-bottom flask with a stir bar, compound $5(2 \mathrm{~g}, 6 \mathrm{mmol})$ was dissolved in anhydrous DCM $(10 \mathrm{~mL})$. The mixture was cooled to $0{ }^{\circ} \mathrm{C}$ and diethylaminosulfur trifluoride (DAST, $2.13 \mathrm{~g}$, 2.2 eq.) was added dropwise. After being stirred for $2 \mathrm{~h}$ at room temperature, the reaction was quenched by saturated $\mathrm{NH}_{4} \mathrm{Cl}(40 \mathrm{~mL})$ and extracted with EtOAc $(40 \mathrm{~mL}$, three times). The combined organic phase was dried over $\mathrm{Na}_{2} \mathrm{SO}_{4}$ and concentrated on a rotary evaporator. The residue was purified by flash column chromatography with silica gel (elution with PE/EtOAc =3/1) to afford fluorinated product 6 as a white solid (1.6 g, 80\% yield).

${ }^{1}$ H NMR (500 MHz, Chloroform-d) $\delta 8.27$ (s, 1H), 8.12 (d, $\left.J=10.0 \mathrm{~Hz}, 1 \mathrm{H}\right), 7.40$ (d, $J=8.3 \mathrm{~Hz}$, $2 \mathrm{H}), 7.06(\mathrm{~d}, J=8.4 \mathrm{~Hz}, 2 \mathrm{H}), 7.01(\mathrm{~d}, J=8.7 \mathrm{~Hz}, 1 \mathrm{H}), 6.95(\mathrm{t}, J=55.3 \mathrm{~Hz}, 1 \mathrm{H}), 5.16(\mathrm{~s}, 2 \mathrm{H}), 3.91$ (s, 3H).

${ }^{13}$ C NMR (126 MHz, Chloroform-d) $\delta$ 166.06, 159.68, 140.33, 133.90, 132.19, 128.91, 128.43 (t, $J=6.2 \mathrm{~Hz}), 123.14,123.13$ (t, $J=22.8 \mathrm{~Hz}), 119.41,111.85,111.09$ (t, $J=236.9 \mathrm{~Hz}), 70.05,52.13$.

${ }^{19}$ F NMR (471 MHz, Chloroform-d) $\delta-116.10$ (s, 1F), -116.22 (s, 1F).

FT-HRMS (ESI) $\mathrm{m} / \mathrm{z}$ calcd. for $\mathrm{C}_{16} \mathrm{H}_{13} \mathrm{~F}_{2} \mathrm{~N}_{3} \mathrm{NaO}_{3}[\mathrm{M}+\mathrm{Na}]^{+}$: 356.0817; Found: 356.0818 .

4-((4-azidobenzyl)oxy)-3-(difluoromethyl)benzoic acid (7)

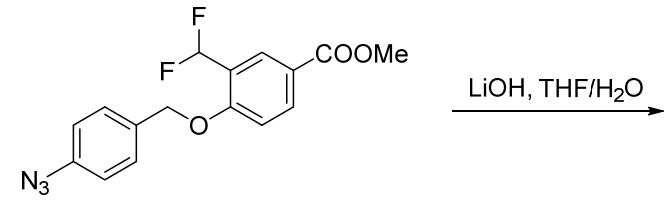

6<smiles>Nc1ccc(COc2ccc(C(=O)O)cc2C(F)F)cc1</smiles>

7 
In a round-bottom flask with a stir bar, compound $6(1 \mathrm{~g}, 3 \mathrm{mmol})$ was dissolved in THF $(20 \mathrm{~mL})$ at room temperature. Then, a solution of $\mathrm{LiOH}(360 \mathrm{mg}, 5.0 \mathrm{eq}$.) in THF/water $(20 \mathrm{~mL} / 10 \mathrm{~mL})$ was added and the mixture was stirred for $30 \mathrm{~min}$ at room temperature. After completion of the hydrolysis monitored by TLC, the mixture was acidified by $1 \mathrm{~N} \mathrm{HCl}$ to $\mathrm{pH} 3$ and extracted with EtOAc $(30 \mathrm{~mL}$, three times). The combined organic phase was washed with brine $(50 \mathrm{~mL})$, dried over $\mathrm{Na}_{2} \mathrm{SO}_{4}$ and concentrated in vacuo to afford hydrolyzed product 7 as a slight-yellow solid $(0.86$ g, $90 \%$ yield), which was carried on without further purification.

${ }^{1}$ H NMR (600 MHz, DMSO-d 6 ) $\delta 12.96(\mathrm{~s}, 1 \mathrm{H}), 8.09-8.05(\mathrm{~m}, 2 \mathrm{H}), 7.58-7.50(\mathrm{~m}, 2 \mathrm{H}), 7.35$ (d, $J$ $=8.5 \mathrm{~Hz}, 1 \mathrm{H}), 7.17(\mathrm{~d}, J=8.5 \mathrm{~Hz}, 2 \mathrm{H}), 7.17(\mathrm{t}, J=54.9 \mathrm{~Hz}, 1 \mathrm{H}), 5.31(\mathrm{~s}, 2 \mathrm{H})$.

${ }^{13}$ C NMR (151 MHz, DMSO-d $\left.\boldsymbol{d}_{\mathbf{6}}\right) \delta 166.78,159.89(\mathrm{t}, J=5.0 \mathrm{~Hz}), 139.68,134.34,133.43,129.83$, $127.91(\mathrm{t}, J=6.3 \mathrm{~Hz}), 123.60,122.62(\mathrm{t}, J=22.2 \mathrm{~Hz}), 119.74,113.65,112.43(\mathrm{t}, J=235.6 \mathrm{~Hz})$, 69.91 .

${ }^{19}$ F NMR (565 MHz, DMSO-d d $^{\delta} \delta-115.27$ (s, 1F), -115.37 (s, 1F).

FT-HRMS (ESI) m/z calcd. for $\mathrm{C}_{15} \mathrm{H}_{10} \mathrm{~F}_{2} \mathrm{~N}_{3} \mathrm{O}_{3}[\mathrm{M}-\mathrm{H}]^{-}: 318.0696$; Found: 318.0698 .

PAB-QM-Bio (19)

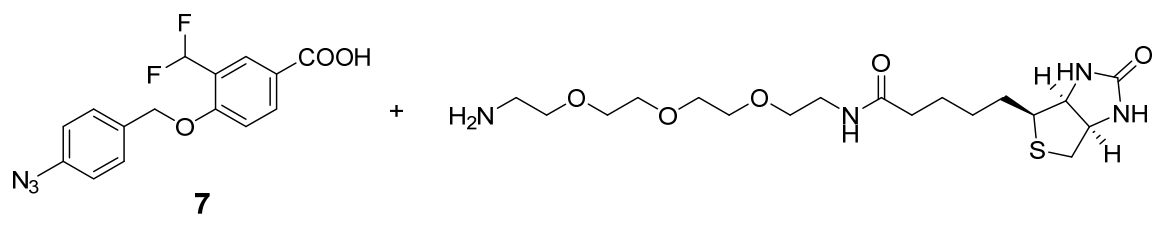

EDCI, HOBt, DIPEA, DMF

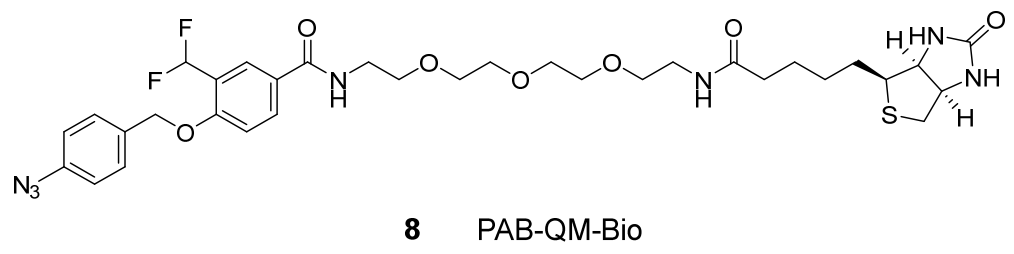

In a dried round-bottom flask with a stir bar, compound $7(32 \mathrm{mg}, 0.1 \mathrm{mmol})$ and anhydrous DCM $(1 \mathrm{~mL})$ was combined under $\mathrm{N}_{2}$ atmosphere. Then DIPEA (0.05 mL, 3.0 eq.), EDCI (19.1 mg, 1.0 eq.) and $\mathrm{HOBt}(13.5 \mathrm{mg}, 1.0 \mathrm{eq})$ were added sequentially. The resulting mixture was stirred at $0{ }^{\circ} \mathrm{C}$ for $1 \mathrm{~h}$, followed by the addition of amino-PEG-biotin ( $38 \mathrm{mg}, 0.9$ eq.). After being stirred at room temperature overnight, the mixture was diluted with EtOAc $(15 \mathrm{~mL})$, and washed sequentially with deionized water $(15 \mathrm{~mL})$, saturated $\mathrm{NaHCO}_{3}(15 \mathrm{~mL})$ and brine $(15 \mathrm{~mL})$. The organic phase was dried over $\mathrm{Na}_{2} \mathrm{SO}_{4}$ and concentrated on a rotary evaporator. The residue was purified by preparative TLC using silica plates (PE/EtOAc $=1 / 1)$ to afford PAB-QM-biotin $(8)$ as white gel $(50 \mathrm{mg}, 70 \%$ yield).

${ }^{1}$ H NMR (500 MHz, Chloroform-d) $\delta 8.05(\mathrm{~s}, 1 \mathrm{H}), 7.99(\mathrm{dd}, J=8.7,2.2 \mathrm{~Hz}, 1 \mathrm{H}), 7.40(\mathrm{~d}, J=8.2$ $\mathrm{Hz}, 2 \mathrm{H}), 7.24$ (t, $J=5.4 \mathrm{~Hz}, 1 \mathrm{H}), 7.07-7.00(\mathrm{~m}, 3 \mathrm{H}), 6.96(\mathrm{t}, J=55.3 \mathrm{~Hz}, 1 \mathrm{H}), 6.61$ (t, $J=5.6 \mathrm{~Hz}$, $1 \mathrm{H}), 6.45$ (s, 1H), $5.48(\mathrm{~s}, 1 \mathrm{H}), 5.15$ (s, 2H), 4.47 (dd, $J=7.8,4.8 \mathrm{~Hz}, 1 \mathrm{H}), 4.27$ (dd, $J=7.8,4.6$ $\mathrm{Hz}, 1 \mathrm{H}), 3.71-3.61(\mathrm{~m}, 10 \mathrm{H}), 3.61-3.57(\mathrm{~m}, 2 \mathrm{H}), 3.52(\mathrm{t}, J=5.2 \mathrm{~Hz}, 2 \mathrm{H}), 3.42-3.35(\mathrm{~m}, 2 \mathrm{H}), 3.17-$ 
$3.05(\mathrm{~m}, 1 \mathrm{H}), 2.88(\mathrm{dd}, J=12.8,4.9 \mathrm{~Hz}, 1 \mathrm{H}), 2.72(\mathrm{~d}, J=12.8 \mathrm{~Hz}, 1 \mathrm{H}), 2.19(\mathrm{t}, J=7.5 \mathrm{~Hz}, 2 \mathrm{H})$, $1.73-1.56(\mathrm{~m}, 4 \mathrm{H}), 1.46-1.35(\mathrm{~m}, 2 \mathrm{H})$.

${ }^{13}$ C NMR (126 MHz, Chloroform-d) $\delta$ 173.28, 166.28, 163.95, 158.50, 140.23, 132.39, 131.82, 128.95, 127.30, $125.43(\mathrm{t}, J=5.5 \mathrm{~Hz}), 122.77(\mathrm{t}, J=22.3 \mathrm{~Hz}), 119.36,112.14,111.29$ (t, $J=236.7$ $\mathrm{Hz}), 70.43,70.35,70.21,70.05,70.00,69.90,69.87,61.80,60.21,55.52,40.49,39.91,39.12,35.89$, $28.14,28.08,25.55$.

${ }^{19}$ F NMR (471 MHz, Chloroform-d) $\delta-115.55$ (s, 1F), -115.67 (s, 1F).

FT-HRMS (ESI) $\mathrm{m} / \mathrm{z}$ calcd. for $\mathrm{C}_{33} \mathrm{H}_{44} \mathrm{~F}_{2} \mathrm{~N}_{7} \mathrm{O}_{7} \mathrm{~S}[\mathrm{M}+\mathrm{H}]^{+}:$720.2986; Found: 720.2993 .

\section{Synthesis of PAB-caged rhodamine probe}

4-azidobenzyl (4-nitrophenyl) carbonate (4)

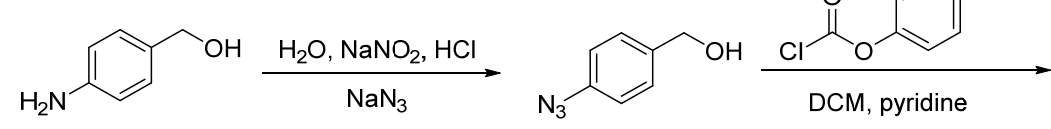

3 PAB-OH

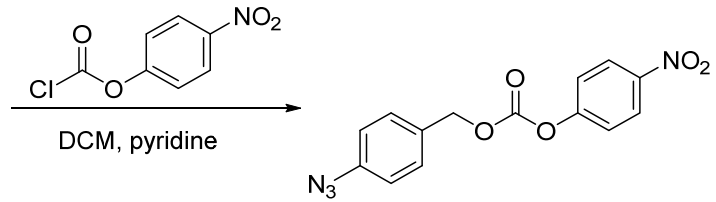

9

To a stirring solution of (4-aminophenyl)methanol $(6.16 \mathrm{~g}, 50 \mathrm{mmol})$ in $6 \mathrm{~N} \mathrm{HCl}(35 \mathrm{~mL}), 125 \mathrm{~mL}$ of $\mathrm{NaNO}_{2}$ (4.14 g, 1.2 eq.) aqueous solution was added dropwise at $0{ }^{\circ} \mathrm{C}$, and the resulting mixture was stirred for 20 minutes at $0{ }^{\circ} \mathrm{C}$. Then, $75 \mathrm{~mL}^{\circ} \mathrm{NaN}_{3}(9.75 \mathrm{~g}, 3.0 \mathrm{eq})$ aqueous solution was added dropwise while stirring at $0{ }^{\circ} \mathrm{C}$, and the mixture was kept stirred for $1.5 \mathrm{~h}$ at this temperature. After completion of the reaction, the mixture was diluted with deionized water $(100 \mathrm{~mL})$, and extracted carefully with EtOAc (100 mL, three times). The combined organic phase was washed sequentially with saturated $\mathrm{NaHCO}_{3}(100 \mathrm{~mL}$, twice $)$ and brine $(100 \mathrm{~mL})$, dried over $\mathrm{Na}_{2} \mathrm{SO}_{4}$, and concentrated on a rotary evaporator to afford the crude product, which was purified by recrystallization (EtOAc/PE) to give (4-azidophenyl)methanol (PAB-OH, 3) as yellow crystals (6 $\mathrm{g}, 81 \%$ yield).

A dried round-bottom flask with a stir bar was charged with PAB-OH (4 g, $26.6 \mathrm{mmol})$, then evacuated and backfilled with $\mathrm{N}_{2}$ three times. Anhydrous DCM (48 mL), pyridine ( $4.3 \mathrm{~mL}, 2.0$ eq.) and 4-nitrophenyl carbonochloridate (5.9 g, $1.1 \mathrm{eq}$ ) were added sequentially while stirring at room temperature. After being stirred at room temperature overnight, the mixture was diluted with water $(100 \mathrm{~mL})$ and extracted with DCM $(80 \mathrm{~mL}$, three times). The combined organic phase was washed with brine $(80 \mathrm{~mL})$, dried over $\mathrm{Na}_{2} \mathrm{SO}_{4}$, and concentrated on a rotary evaporator. The residue was purified by flash column chromatography on silica gel (elution with $\mathrm{PE} / \mathrm{DCM}=1: 2$ ) to afford 4azidobenzyl (4-nitrophenyl) carbonate (9) as light-yellow crystals (7 g, 84\% yield). The ${ }^{1} \mathrm{H}$ NMR and ${ }^{13} \mathrm{C}$ NMR spectrum of compound 9 matched the previously reported spectral data ${ }^{2}$.

4-azidobenzyl carbamate (10)

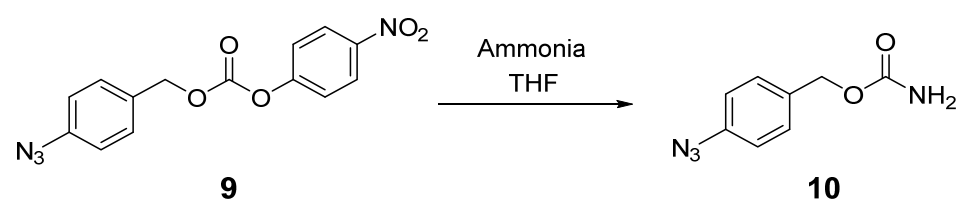


In a round-bottom flask with a stir bar, compound $9(0.5 \mathrm{~g}, 1.6 \mathrm{mmol})$ was dissolved in THF $(8 \mathrm{~mL})$. Then ammonia solution ( $3 \mathrm{~mL}, 28 \% \mathrm{wt})$ was added and the mixture was stirred at room temperature for $2 \mathrm{~h}$. After completion of the reaction monitored by TLC, $\mathrm{NaOH}$ solution (1M) was added dropwise until the aqueous phase became colorless. Then the organic phase was washed with brine $\left(20 \mathrm{~mL}\right.$ ), dried over $\mathrm{Na}_{2} \mathrm{SO}_{4}$ and concentrated in vacuo to afford product $\mathbf{1 0}$ as a slight-yellow solid (274 mg, 90\% yield), which was carried on without further purification.

${ }^{1}$ H NMR (400 MHz, Chloroform-d) $\delta 7.36(\mathrm{~d}, J=8.0 \mathrm{~Hz}, 2 \mathrm{H}), 7.02(\mathrm{~d}, J=8.0 \mathrm{~Hz}, 2 \mathrm{H}), 5.07$ (s, 2H), 4.76 (brs, 2H).

${ }^{13}$ C NMR (101 MHz, Chloroform-d) $\delta$ 156.56, 140.06, 132.96, 129.87, 119.15, 66.32.

FT-HRMS (ESI) m/z calcd. for $\mathrm{C}_{8} \mathrm{H}_{8} \mathrm{~N}_{4} \mathrm{NaO}_{2}[\mathrm{M}+\mathrm{Na}]^{+}: 215.0539$; Found: 215.0537 .

PAB-rhodamine (11)

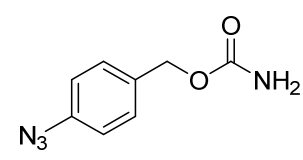

10

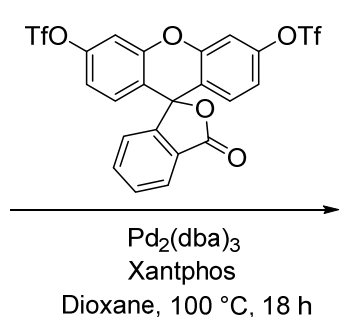

Dioxane, $100^{\circ} \mathrm{C}, 18 \mathrm{~h}$

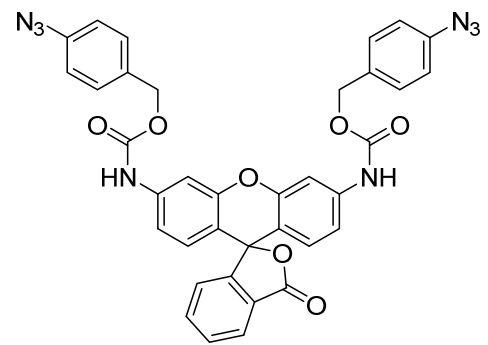

11

PAB-rhodamine was prepared according to the procedure described in Luke D. Lavis's work ${ }^{3}$ with minor modifications. Briefly, in a dried round-bottom flask with a stir bar, fluorescein bis(trifluoromethanesulfonate) $(250 \mathrm{mg}, 0.419 \mathrm{mmol})$ and anhydrous 1,4-dioxane $(1 \mathrm{~mL})$ was combined under $\mathrm{N}_{2}$ atmosphere. Then compound 10 (194 mg, $1.01 \mathrm{mmol}, 2.4 \mathrm{eq}$.), $\mathrm{Pd}_{2}(\mathrm{dba})_{3}(38 \mathrm{mg}$, $0.042 \mathrm{mmol}, 0.1$ eq.), Xantphos (73 mg, $0.126 \mathrm{mmol}, 0.3$ eq.), and $\mathrm{Cs}_{2} \mathrm{CO}_{3}(382 \mathrm{mg}, 1.17 \mathrm{mmol}, 2.8$ eq.) was added and the mixture was stirred at $80{ }^{\circ} \mathrm{C}$ for $3 \mathrm{~h}$. The resulting mixture was then cooled to room temperature and filtered through celite with DCM. The solvents were removed and the residue was purified by preparative TLC using silica plates $(\mathrm{PE} / \mathrm{EtOAc}=1 / 1)$ to afford PABrhodamine (11) as an orange solid (143 $\mathrm{mg}, 50 \%$ yield).

${ }^{1}$ H NMR (400 MHz, Chloroform-d) $\delta 8.01(\mathrm{dd}, J=7.0,1.3 \mathrm{~Hz}, 1 \mathrm{H}), 7.63(\mathrm{dtd}, J=19.4,7.4,1.2$ $\mathrm{Hz}, 2 \mathrm{H}), 7.48$ (s, 2H), 7.39 (d, $J=8.5 \mathrm{~Hz}, 4 \mathrm{H}), 7.12$ (d, $J=7.4 \mathrm{~Hz}, 1 \mathrm{H}), 7.02(\mathrm{~d}, J=8.5 \mathrm{~Hz}, 4 \mathrm{H})$, 6.94 (dd, $J=8.6,2.2 \mathrm{~Hz}, 2 \mathrm{H}), 6.86(\mathrm{~s}, 2 \mathrm{H}), 6.69$ (d, $J=8.6 \mathrm{~Hz}, 2 \mathrm{H}), 5.17$ (s, 4H).

${ }^{13}$ C NMR (101 MHz, Chloroform-d) $\delta$ 169.51, 153.17, 152.89, 151.84, 140.34, 139.90, 135.16, $132.45,130.12,129.84,128.73,126.39,125.12,123.90,119.24,114.30,113.72,106.41,82.54$, 66.69 .

FT-HRMS (ESI) m/z calcd. for $\mathrm{C}_{36} \mathrm{H}_{25} \mathrm{~N}_{8} \mathrm{O}_{7}[\mathrm{M}+\mathrm{H}]^{+}:$: 681.1841; Found: 681.1855 .

\section{Photocatalyst screening}

4-azidobenzoic acid $1(0.1 \mathrm{mmol})$ and NADH $(0.2 \mathrm{mmol})$ were mixed in $0.5 \mathrm{~mL} \mathrm{H}_{2} \mathrm{O} / \mathrm{DMSO}(1: 1)$ supplemented with photocatalyst ( $10 \mathrm{~mol} \%, 0.01 \mathrm{mmol}$, Supporting Table 1). The resulting mixture 
were irradiated by white LED $\left(4 \mathrm{~mW} / \mathrm{cm}^{2}\right)$ at room temperature for $30 \mathrm{~min}$, and subjected to HPLC analysis after dilution. Chromatograms were recorded on 1260 infinity II analytical HPLC system (Agilent). For the tracking of reaction using Ir8 as the catalyst, reactions mixtures were irradiated for $1,2,5,10$ and $15 \mathrm{~min}$ by mild blue LED $\left(4 \mathrm{~mW} / \mathrm{cm}^{2}\right)$ before HPLC analysis respectively. Reactions were analyzed on a 1260 infinity II analytical HPLC system (Agilent) equipped with a Poroshell 120 EC-C18 column $(2.7 \mu \mathrm{m}, 3.0 \times 150 \mathrm{~mm})$. Peaks were detected using 260 -nm detector. Mobile phases: A ( $0.5 \%$ formic acid in $\mathrm{H}_{2} \mathrm{O}$ ), B (methanol). Flow rate $=0.5 \mathrm{~mL} / \mathrm{min}$; Eluent A/B gradually changed from $95 / 5$ to $0 / 100$ in $8 \mathrm{~min}$.

\section{HPLC analysis of photocatalytic decaging of PAB-QM-Bio}

PAB-QM-Bio (0.1 mM) was mixed with NADH $(0.5 \mathrm{mM})$ and Ir8 (10 mol\%) in 10:1 DMSO/PBS (pH 7.4) buffer, and irradiated by mild blue LED $\left(4 \mathrm{~mW} / \mathrm{cm}^{2}\right)$ for $15 \mathrm{~min}$ at room temperature. Groups without light irradiation or Ir8 were used as controls. Reactions were analyzed on an ACQUITY UPLC I-Class (Waters) system equipped with a BEH C18 Acquity column $(1.7 \mu \mathrm{m}$, $2.1 \times 50 \mathrm{~mm}$ ). Peaks were detected using 240-nm detector. Mobile phases: A $(\mathrm{MeCN}), \mathrm{B}(5 \% \mathrm{MeCN}$ in $\mathrm{H}_{2} \mathrm{O}$ ). Flow rate $=0.3 \mathrm{~mL} / \mathrm{min}$; Eluent $\mathrm{A} / \mathrm{B}$ gradually changed from $5 / 95$ to $100 / 0$ in $4 \mathrm{~min}$.

\section{Photocatalytic decaging of PAB-QM-Bio for BSA labeling}

Ir8 $(0,0.2,0.5,1.0,2.0,5.0 \mu \mathrm{M})$ was combined with PAB-QM-Bio $(100 \mu \mathrm{M})$, NADH $(500 \mu \mathrm{M})$ and BSA $(10 \mu \mathrm{M})$ in PBS (pH 7.4) to afford reaction mixtures with total solution volume of $100 \mu \mathrm{L}$. The samples were then irradiated by mild blue LED $\left(4 \mathrm{~mW} / \mathrm{cm}^{2}\right)$ for $15 \mathrm{~min}$ at room temperature. $30 \mu \mathrm{L}$ of each sample was taken and combined with $20 \mu \mathrm{L} 5 \mathrm{X}$ SDS-PAGE non-reducing loading buffer (CWBIO) followed by heating at $95{ }^{\circ} \mathrm{C}$ for 10 minutes. Immunoblotting was performed with $4-15 \%$ gradient SDS-PAGE and $0.45 \mu \mathrm{m}$ PVDF membrane according to the general protocol described above. Mouse anti-biotin mAb (Santa Cruz, sc-101339, 1:1,000 dilution) and HRP-linked anti-mouse IgG (Cell Signaling Technology, 7076S, 1:5,000 dilution) were used as primary and secondary antibodies, respectively.

For time-tracking analysis of the reaction, Ir8 $(5 \mu \mathrm{M})$ was combined with PAB-QM-Bio $(100 \mu \mathrm{M})$, NADH $(500 \mu \mathrm{M})$ and BSA $(1 \mathrm{mg} / \mathrm{mL})$ in PBS $(\mathrm{pH} 7.4)$ with total solution volume of $5 \mathrm{~mL}$. The resulting mixture was distributed on 96 -well plate $(100 \mu \mathrm{L} /$ well) and kept in dark. $80 \mu \mathrm{L}$ aliquot was taken every two minutes, and combined with $20 \mu \mathrm{L} 5 \mathrm{X}$ SDS-PAGE non-reducing loading buffer. At given time points $(4.5,10.5$ and $16.5-\mathrm{min})$, the plate was pulsed with irradiation (1 min duration) by mild blue LED $\left(4 \mathrm{~mW} / \mathrm{cm}^{2}\right)$. The taken aliquots were analyzed by Coomassie staining and Immunoblotting (4-15\% gradient SDS-PAGE and $0.45 \mu \mathrm{m}$ PVDF membrane). Streptavidin-HRP (Beyotime, A0303, 1:2,000 dilution) was used to detect the biotinylated bands. 


\section{SUPPORTING FIGURES}
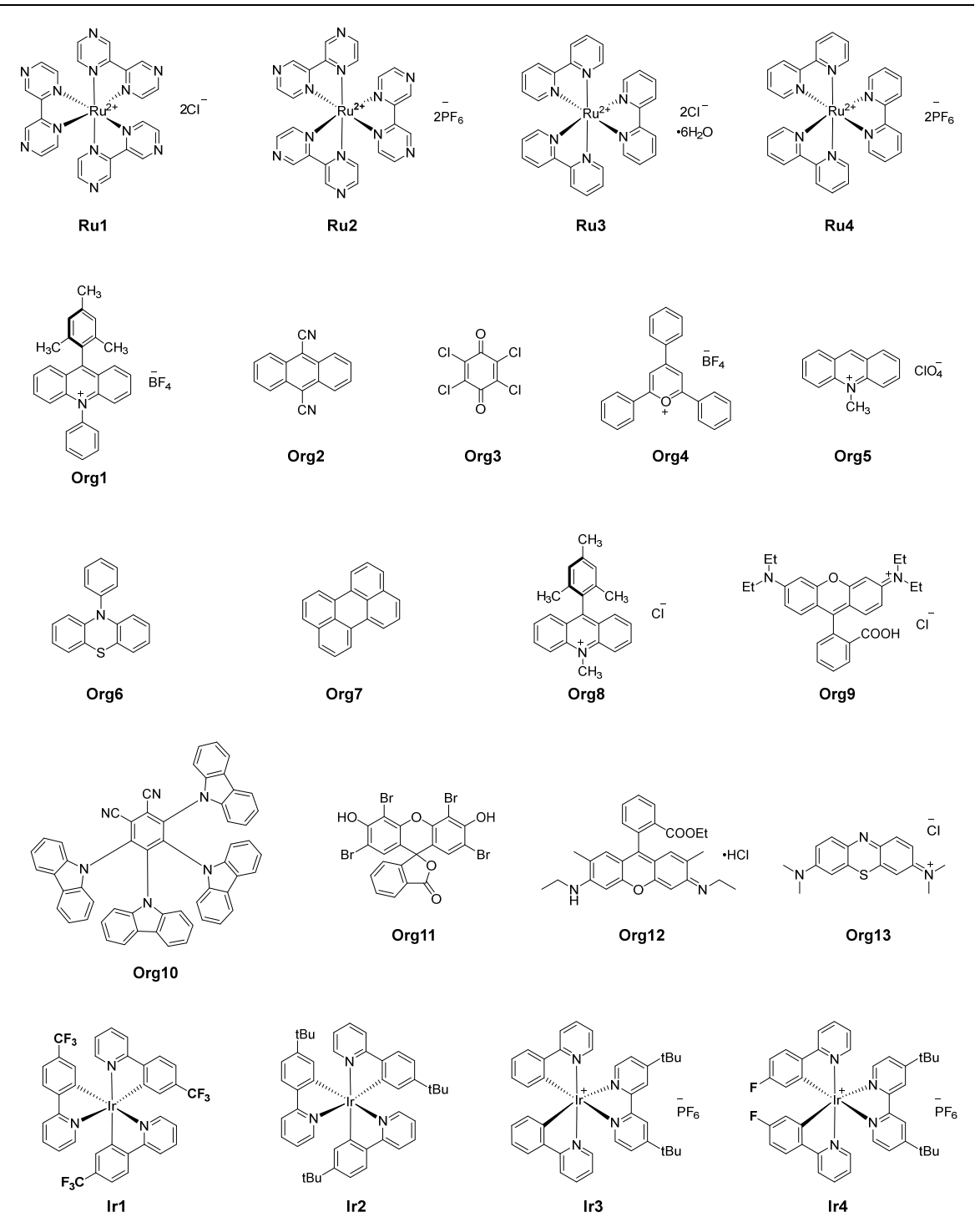

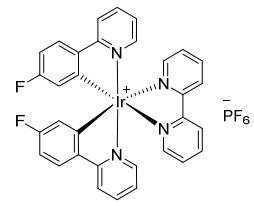

Ir5

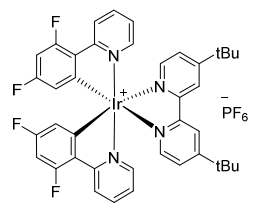

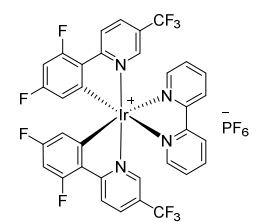

Ir7

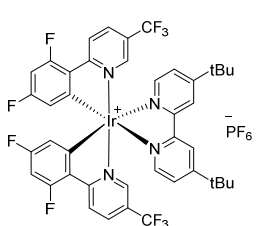

Ir8

Supporting Fig. 1 | Chemical structures of photocatalysts for screening 
a

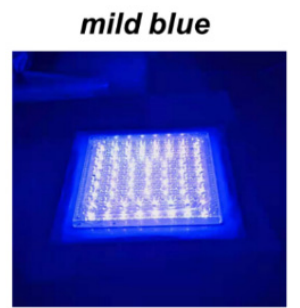

b

\section{medium blue}

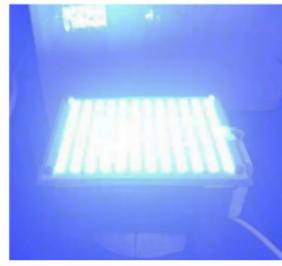

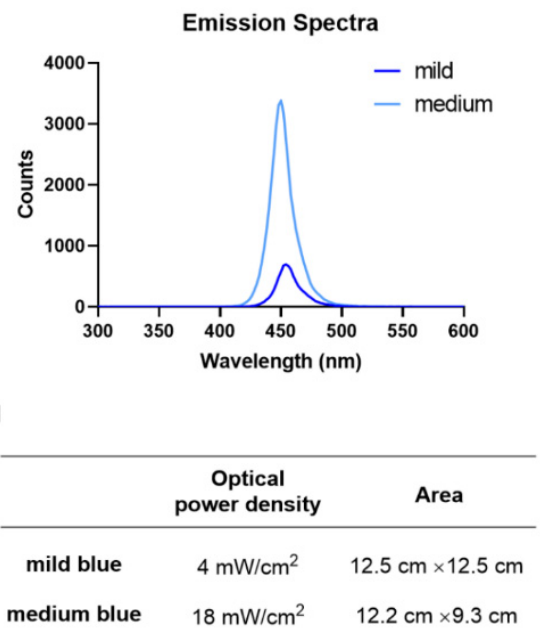

Supporting Fig. 2 | Blue LED light sources used in the study. a, Photograph of mild blue LED used in the study. b, Photograph of medium blue LED used in the study. c, Emission spectra of the blue LEDs. d, Summary table of technical parameters of the blue LEDs.

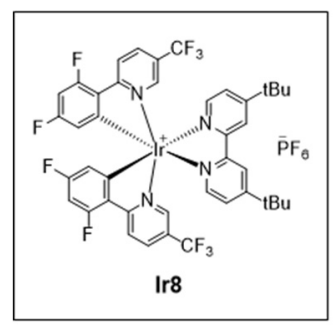

a

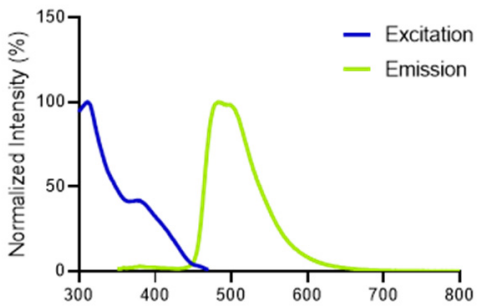

b

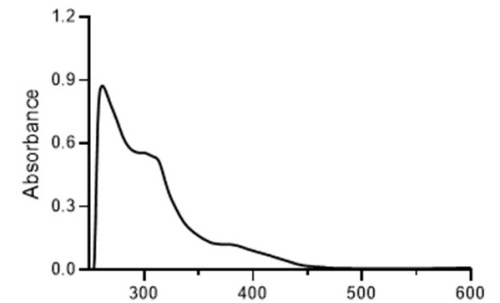

Supporting Fig. 3 | UV-Vis and fluorescent spectra of photocatalyst Ir8. a, Excitation and emission spectra. b, UV-Vis absorbance spectra. All the spectra were recorded at room temperature with $20 \mu \mathrm{M}$ iridium compound in DPBS (pH 7.4, Gibco) in 1-cm cuvette. 


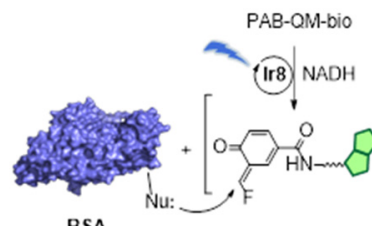

BSA

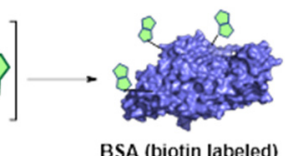

BSA (biotin labeled)

light (1 min) light (1 min) light (1 min)

Time (min) $\quad 0 \quad 2 \quad 4 \vee 6 \quad 8 \quad 10 \vee 12 \quad 14 \quad 16 \vee 18 \quad 20$
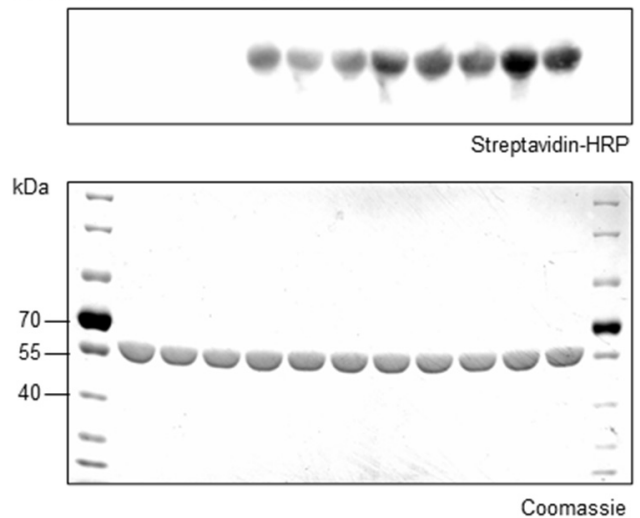

Supporting Fig. 4 | Evaluation of photocatalytic decaging of PAB-QM-bio in vitro. Representative Immunoblotting and Coomassie staining characterization of photocatalytic BSA labeling. Short-duration (1 min) irradiation were pulsed at indicated time points. 

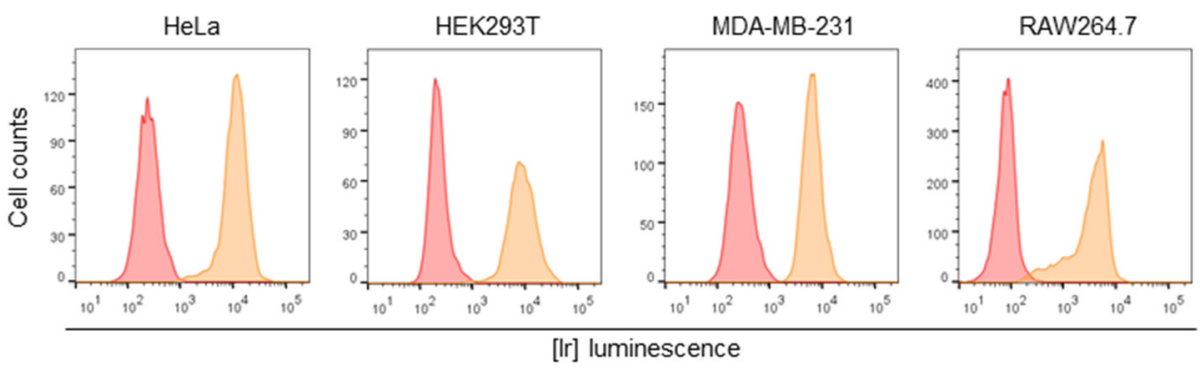

b

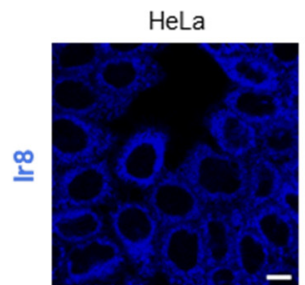

HEK293T

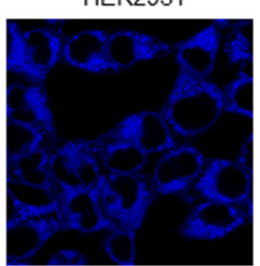

MDA-MB-231

RAW264.7
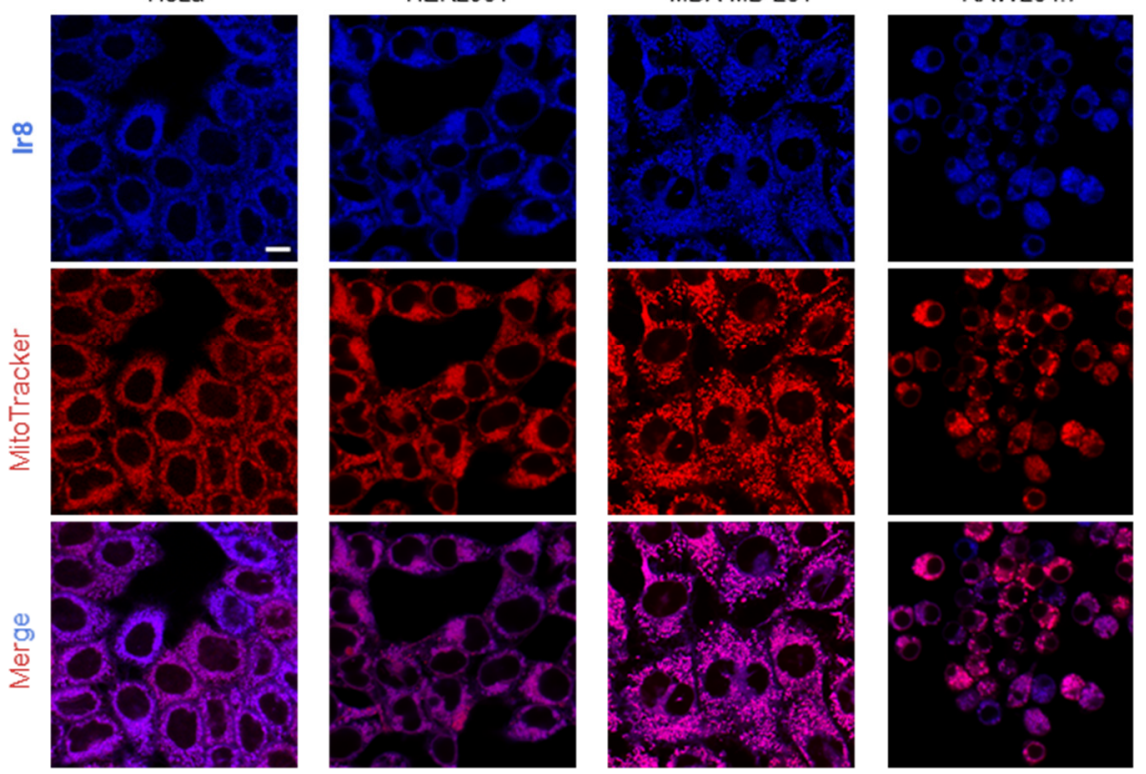

Supporting Fig. 5 | Cellular uptake and colocalization study of photocatalysts. a, Flowcytometry analysis of cellular uptake of cationic Ir8 by different cell lines. b, Live-cell fluorescent imaging of Ir8 in different cell lines. Scale bar, $10 \mu \mathrm{m}$. 
a
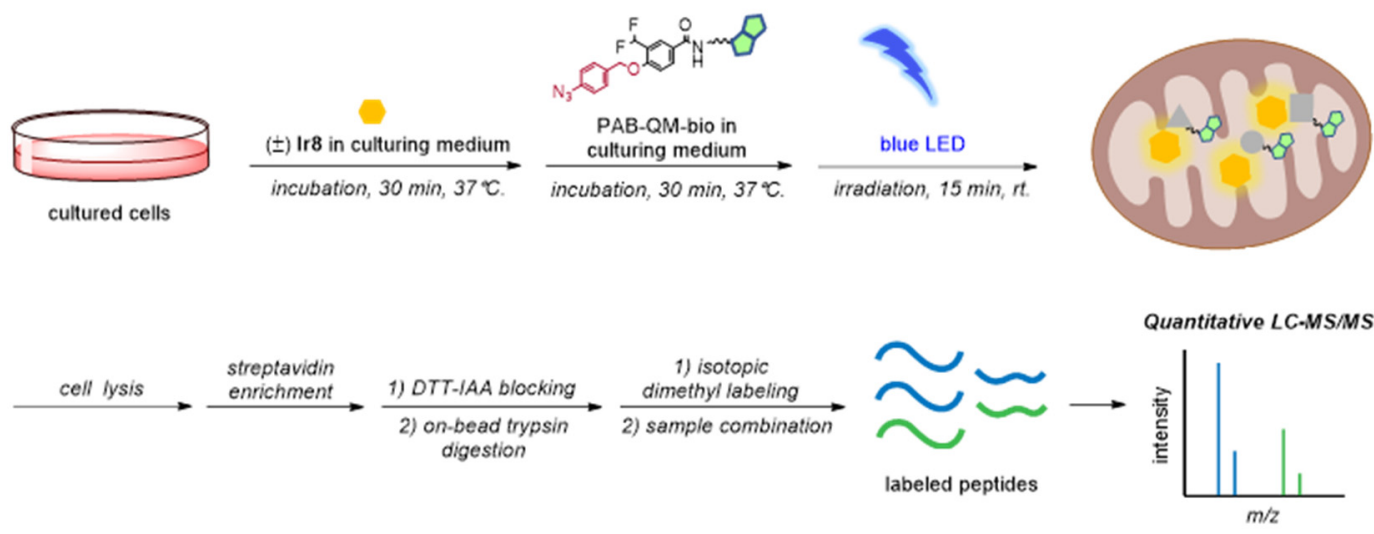

b
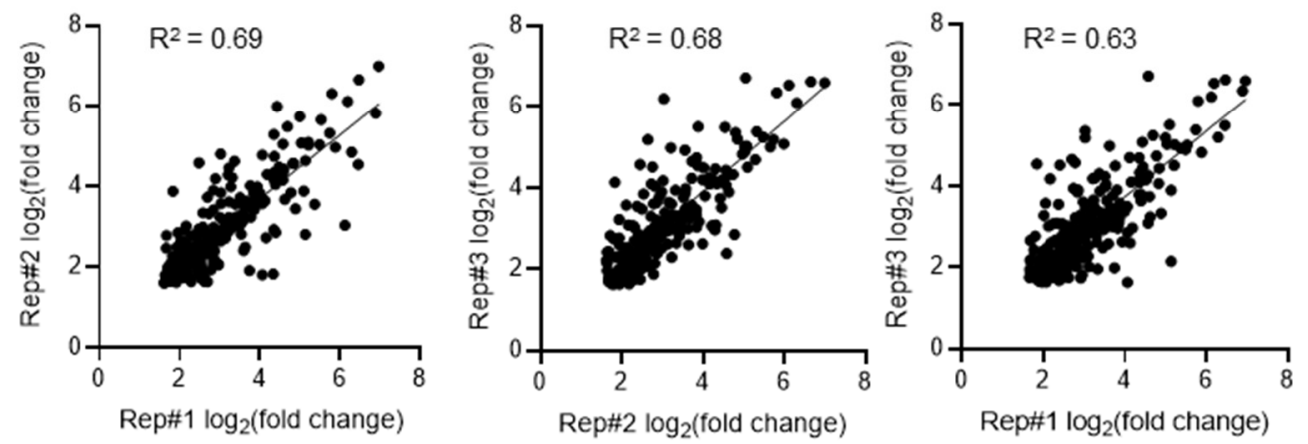

Supporting Fig. 6 | Technical details for photocatalytic proximity labeling in mitochondria. a, Schematic view of the workflow. b, Correlation plots between biological replicates of mitochondrial CAT-Prox in RAW264.7 cells. 
a

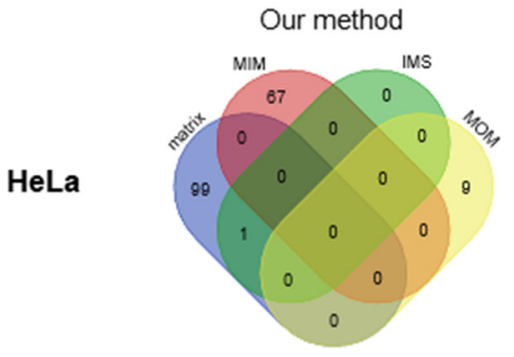

b

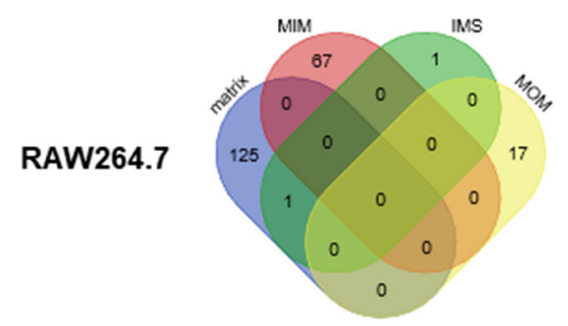

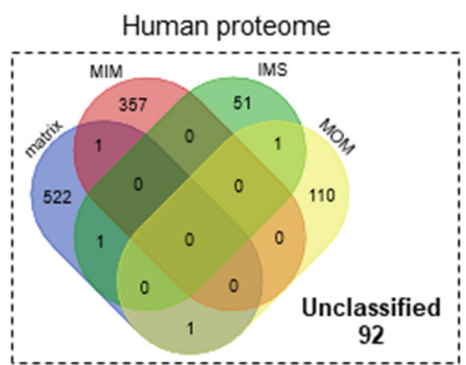

Mouse proteome

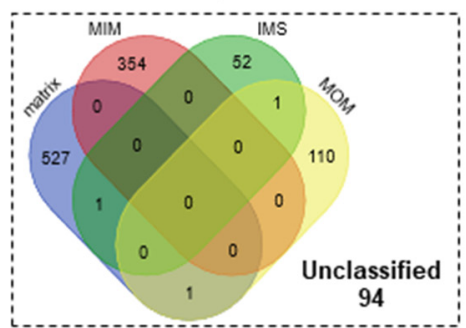

Supporting Fig. 7 | Sub-mitochondrial proteomic analysis of mitochondrial CAT-Prox. a,b, Statistics for HeLa (a) and RAW264.7 (b) cells. The left Venn diagram represents submitochondrial localization of the identified mitochondrial proteins in our study. According to MitoCarta3.0 database, proteins identified as mitochondrial proteins were classified into 'matrix', 'mitochondrial inner membrane (MIM)', 'intermembrane space (IMS)' and 'mithochondrial outer membrane (MOM)'. The Venn diagrams in the right represent submitochondrial localization of whole mouse or human mitochondrial proteins with prior submitochondrial localization annotation in MitoCarta3.0 database. 
a

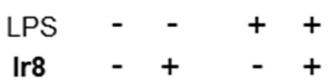

IB: biotin

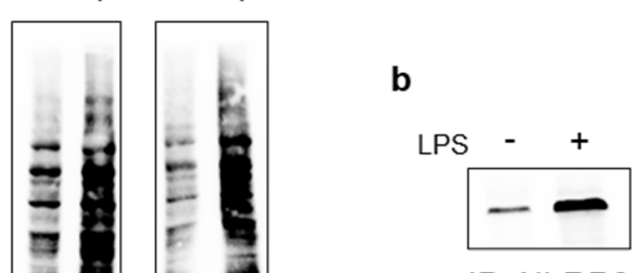

IB: NLRP3

Supporting Fig. 8 | Immunoblotting analysis for CAT-Prox in LPS-stimulated RAW264.7 cells. a, Evaluation of labeling efficiency in LPS-stimulated and normal RAW264.7 cells. b, Immunoblotting analysis of NLRP3 as quality control for LPS-induced stress in RAW264.7 cells. 


\section{REFERENCES}

1. Wang, X. et al. Copper-Triggered Bioorthogonal Cleavage Reactions for Reversible Protein and Cell Surface Modifications. J. Am. Chem. Soc. 141, 17133-17141 (2019).

2. Peltier, R. et al. The rational design of a peptide-based hydrogel responsive to $\mathrm{H}_{2} \mathrm{~S}$. Chem. Commun. (Camb.) 51, 17273-17276 (2015).

3. Grimm, J. B. \& Lavis, L. D. Synthesis of rhodamines from fluoresceins using Pd-catalyzed C-N crosscoupling. Org. Lett. 13, 6354-6357 (2011).

4. Miller, D. C. et al. Anti-Markovnikov Hydroamination of Unactivated Alkenes with Primary Alkyl Amines. J. Am. Chem. Soc. 141, 16590-16594 (2019). 


\section{NMR SPECTRA}

5: ${ }^{1} \mathrm{H}$ NMR (400 MHz, Chloroform- $d$ )

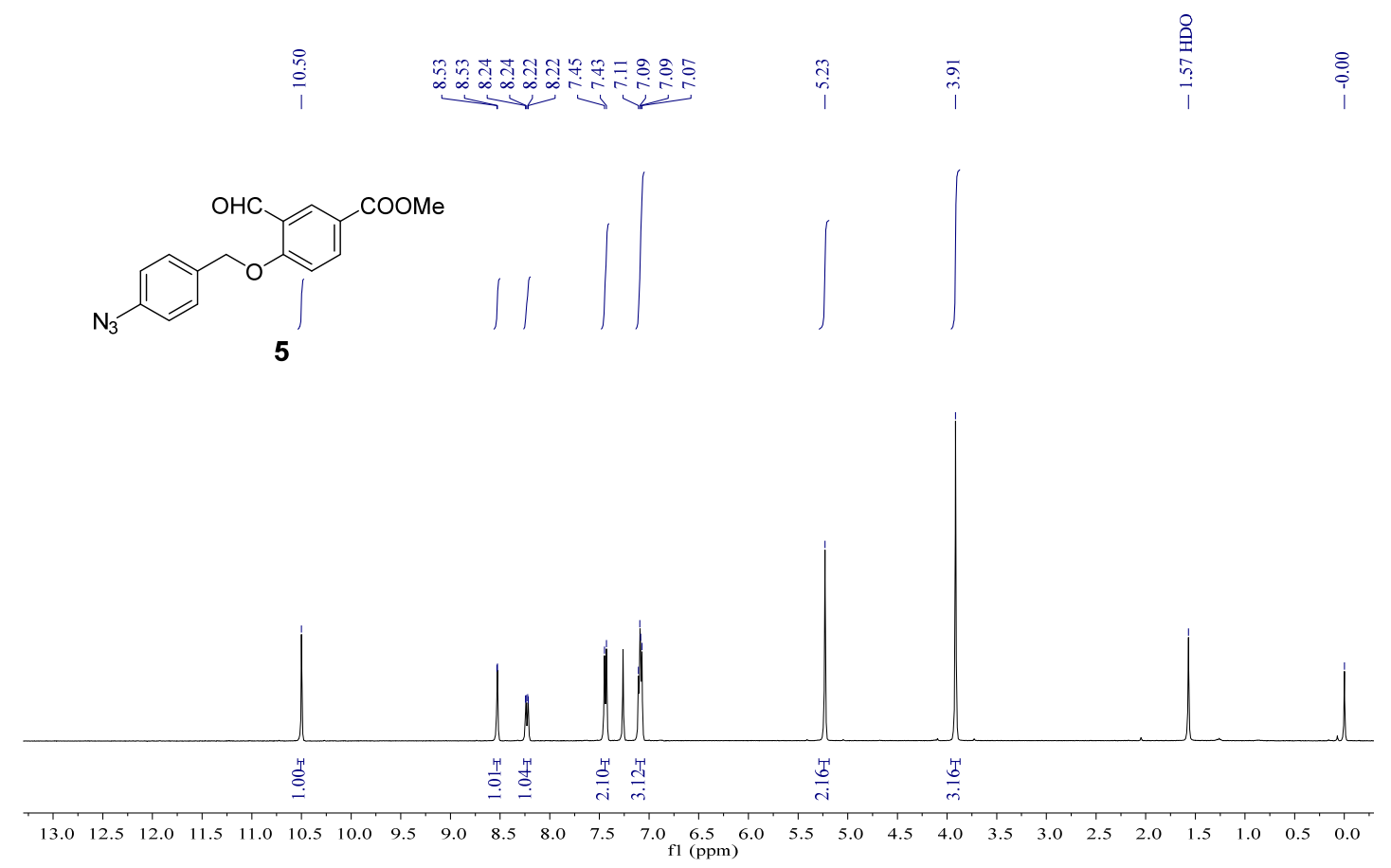

5: ${ }^{13} \mathrm{C}$ NMR (101 MHz, Chloroform- $d$ )
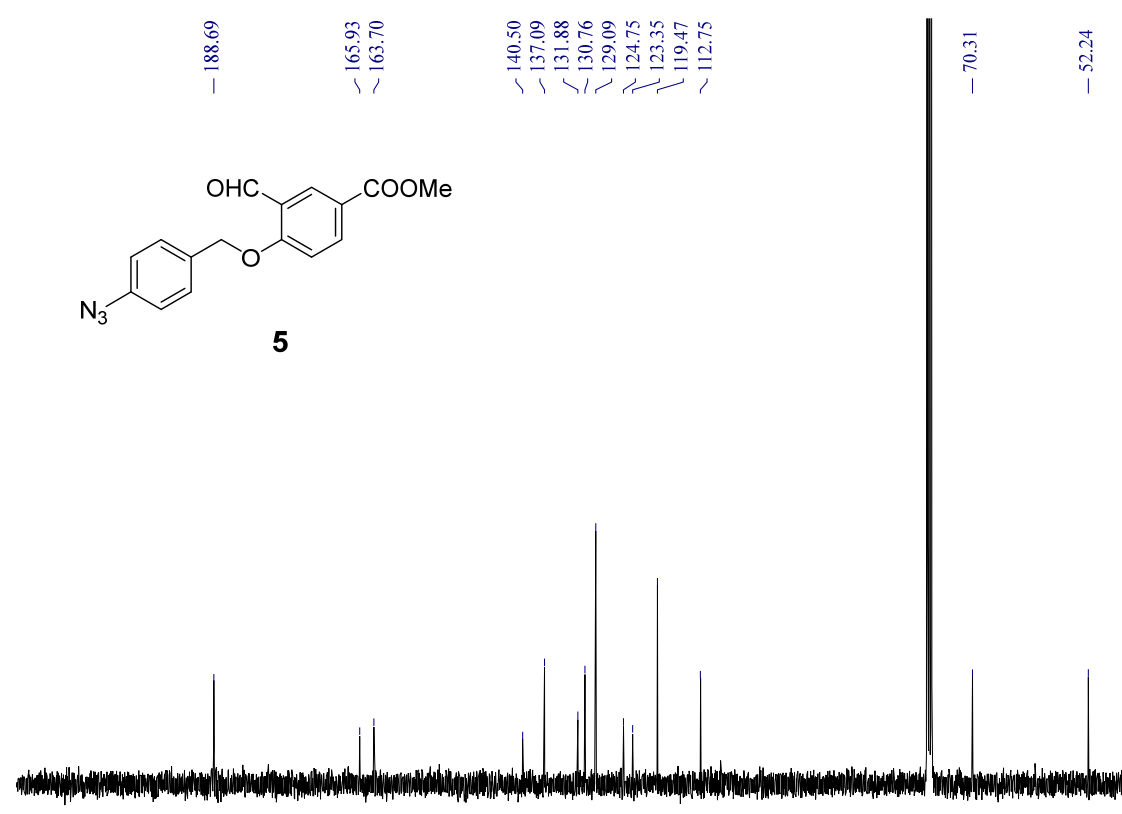

$\begin{array}{lllllllllll}210 & 200 & 190 & 180 & 170 & 160 & 150 & 140 & 130 & 120 & \begin{array}{c}110 \\ \mathrm{f} 1(\mathrm{ppm})\end{array}\end{array}$ 
6: ${ }^{1} \mathrm{H}$ NMR (500 MHz, Chloroform- $d$ )

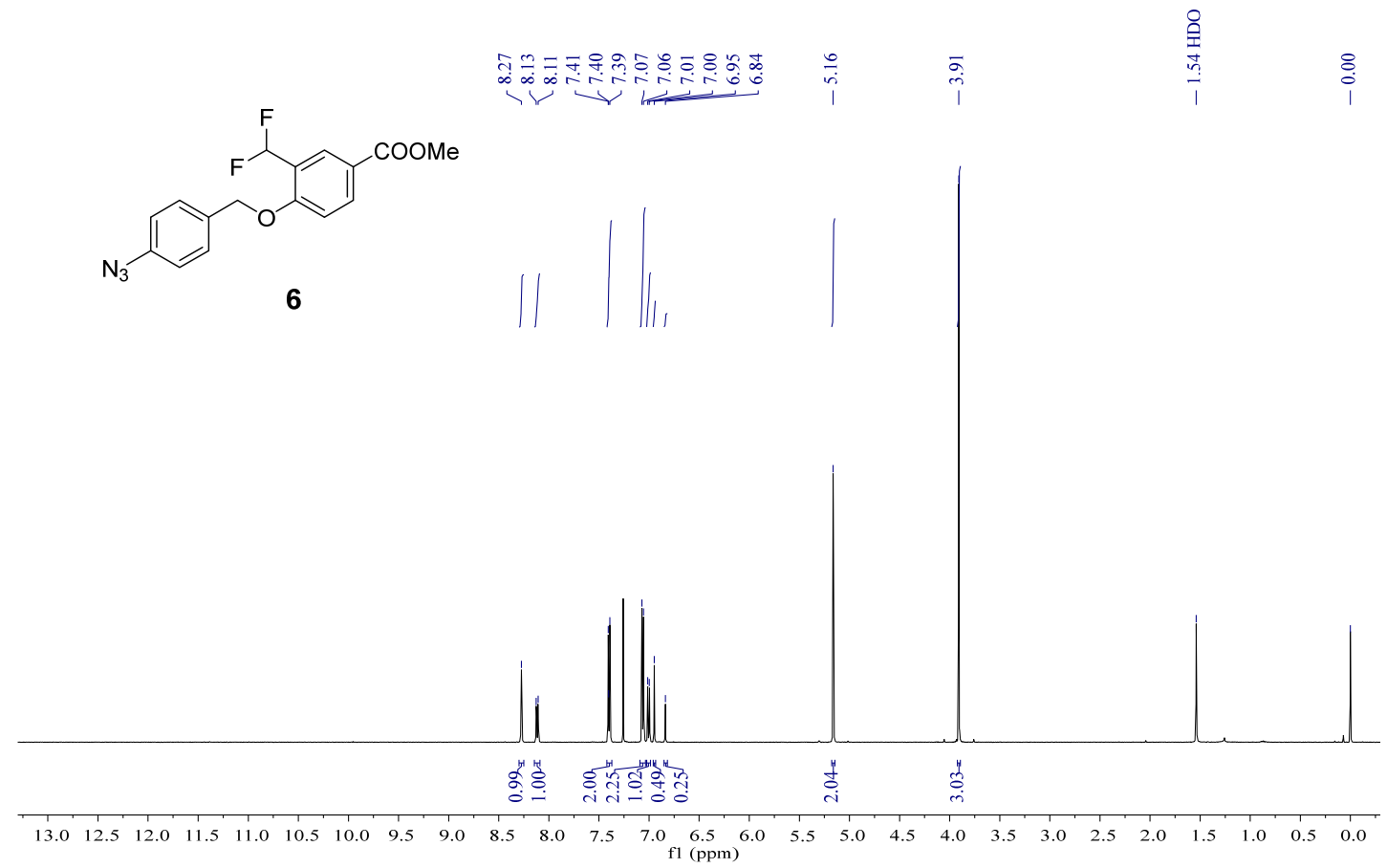

6: ${ }^{13} \mathrm{C}$ NMR (126 MHz, Chloroform- $d$ )
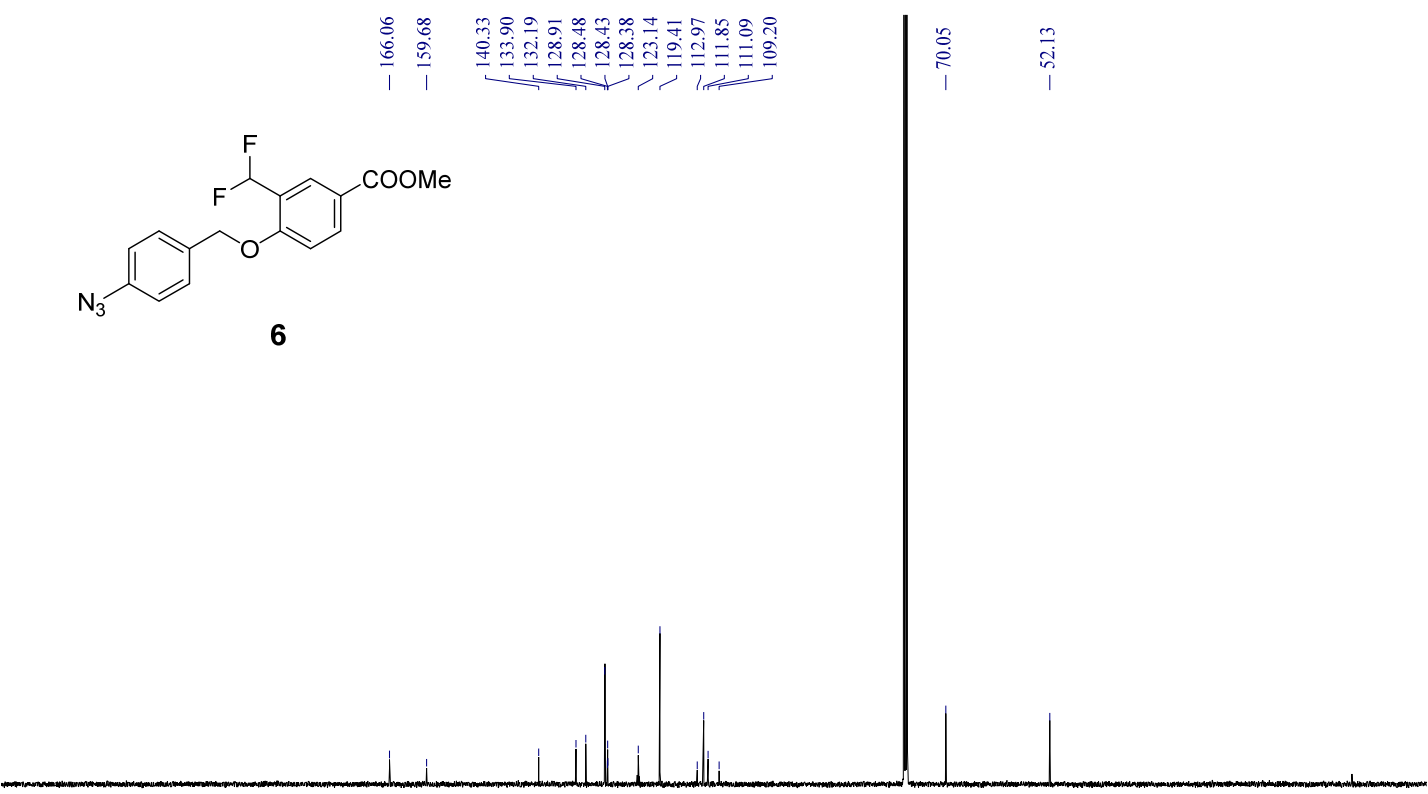

$\begin{array}{lllllllllllllllllllllllllllllllllllll}230 & 220 & 210 & 200 & 190 & 180 & 170 & 160 & 150 & 140 & 130 & 120 & 110 & 100 & 90 & 80 & 70 & 60 & 50 & 40 & 30 & 20 & 10 & 0 & -10\end{array}$ 
6: ${ }^{19}$ F NMR (471 MHz, Chloroform- $d$ )

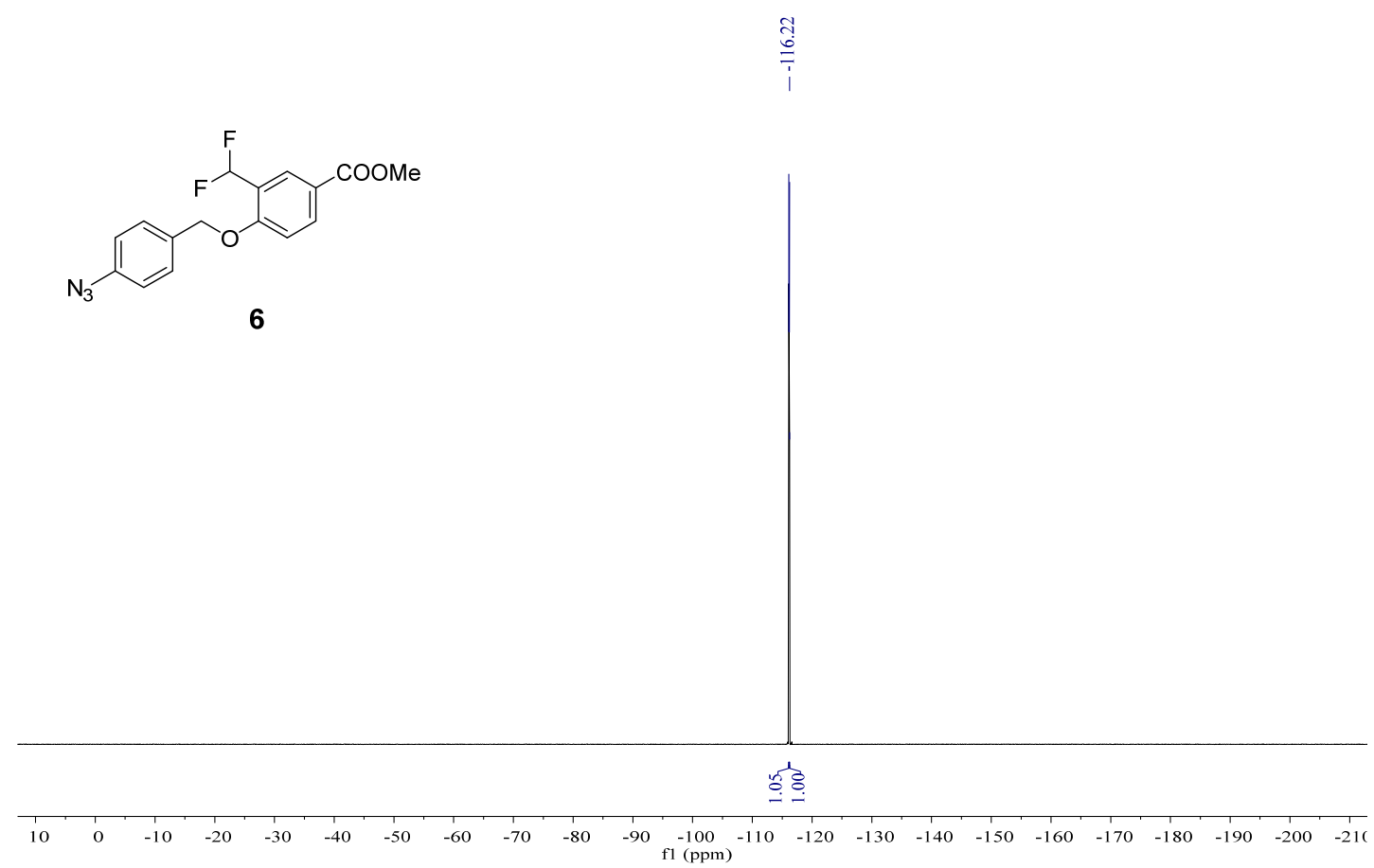

7: ${ }^{1} \mathrm{H}$ NMR $\left(600 \mathrm{MHz}\right.$, DMSO- $\left.d_{6}\right)$

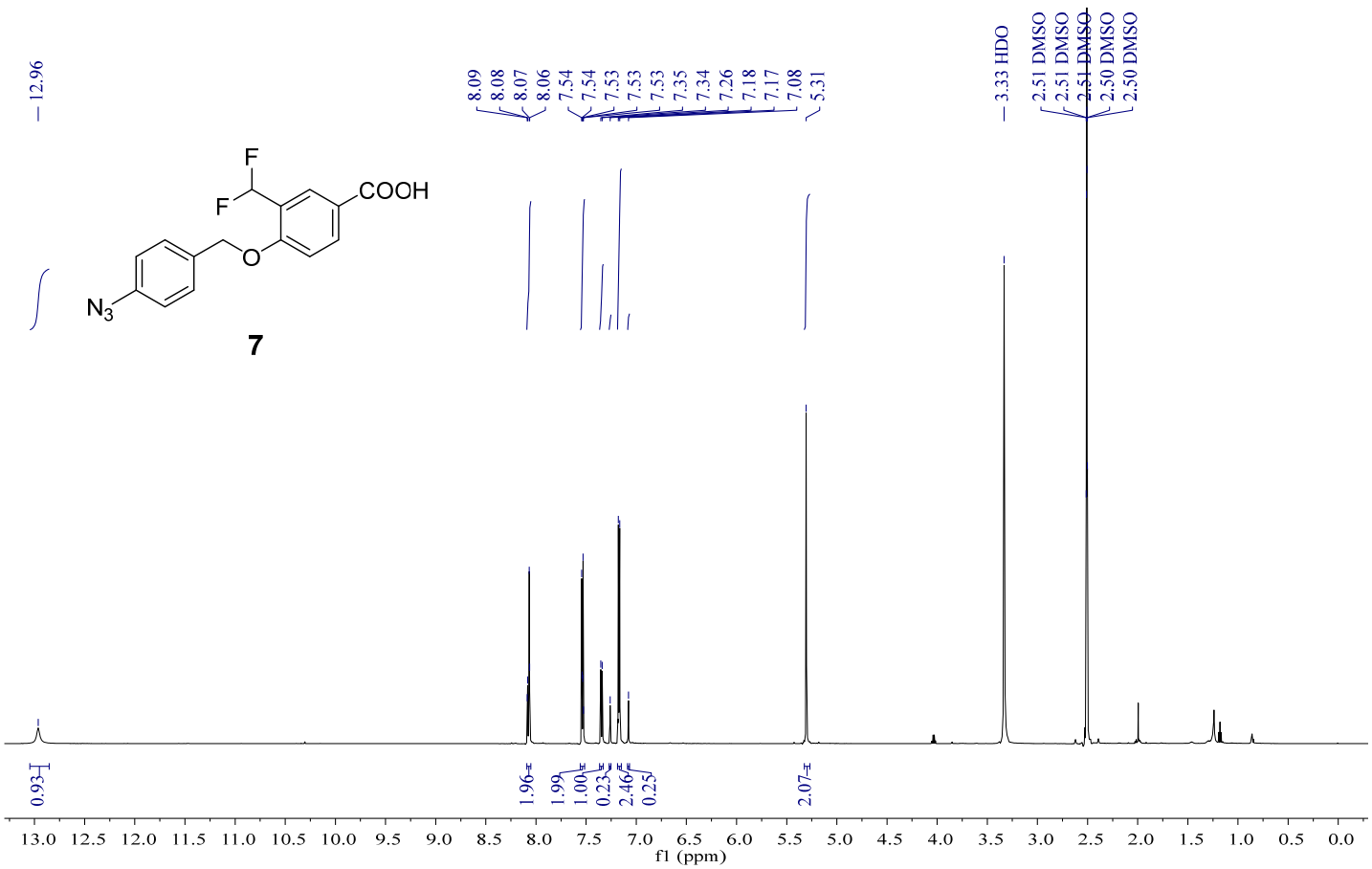


7: ${ }^{13} \mathrm{C}$ NMR $\left(151 \mathrm{MHz}\right.$, DMSO- $\left.d_{6}\right)$

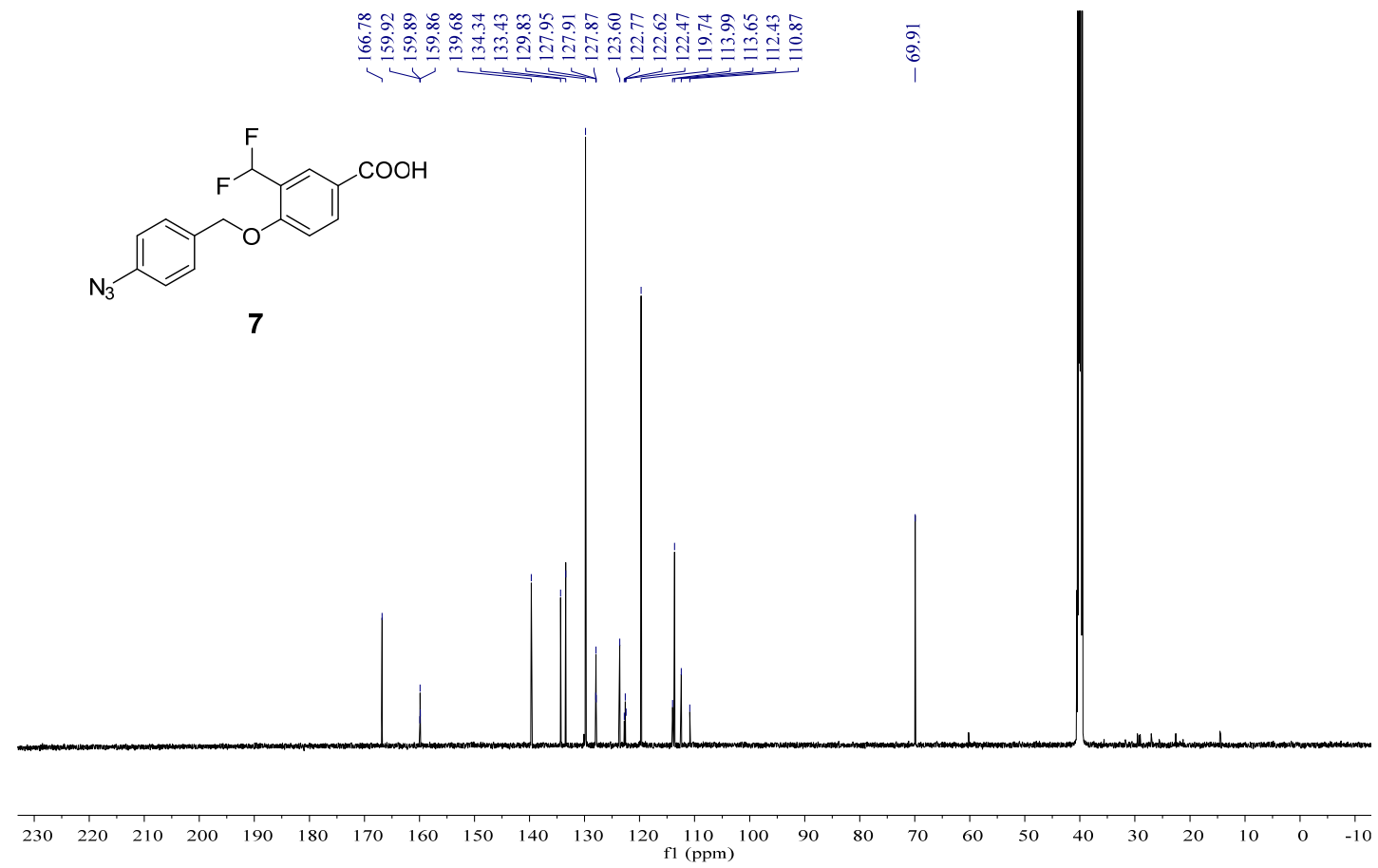

7: ${ }^{19} \mathrm{~F}$ NMR (565 MHz, DMSO- $d_{6}$ )

年年

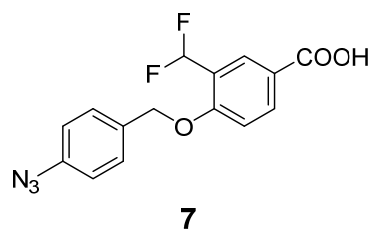

क्षे

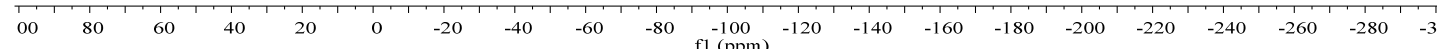




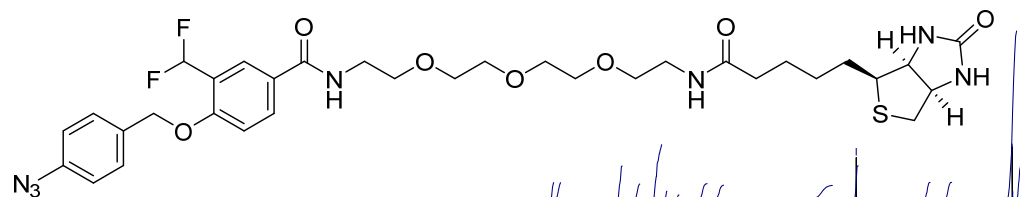

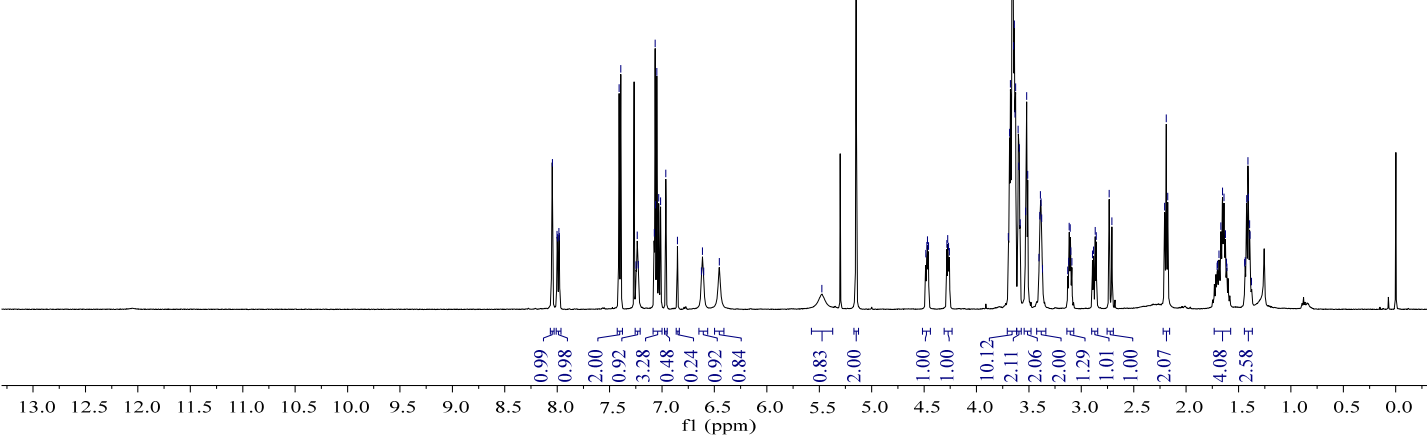

8: ${ }^{13} \mathrm{C}$ NMR $(126 \mathrm{MHz}$, Chloroform- $d$ )

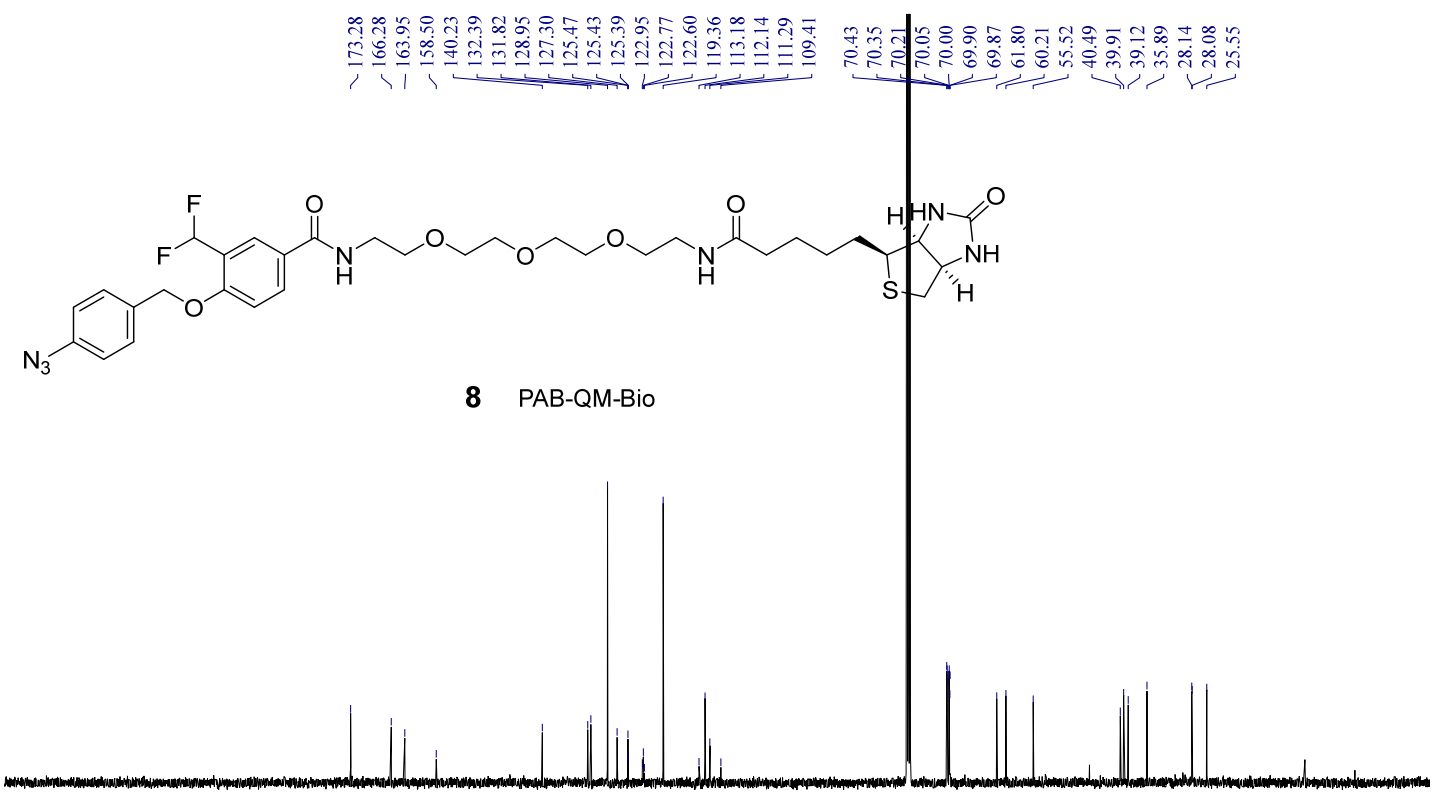

$\begin{array}{llllllllllllllllllllllllllllllllllllllll}230 & 220 & 210 & 200 & 190 & 180 & 170 & 160 & 150 & 140 & 130 & 120 & 110 & 100 & 90 & 80 & 70 & 60 & 50 & 40 & 30 & 20 & 10 & 0 & -10\end{array}$ 
8: ${ }^{19}$ F NMR (471 MHz, Chloroform- $d$ )

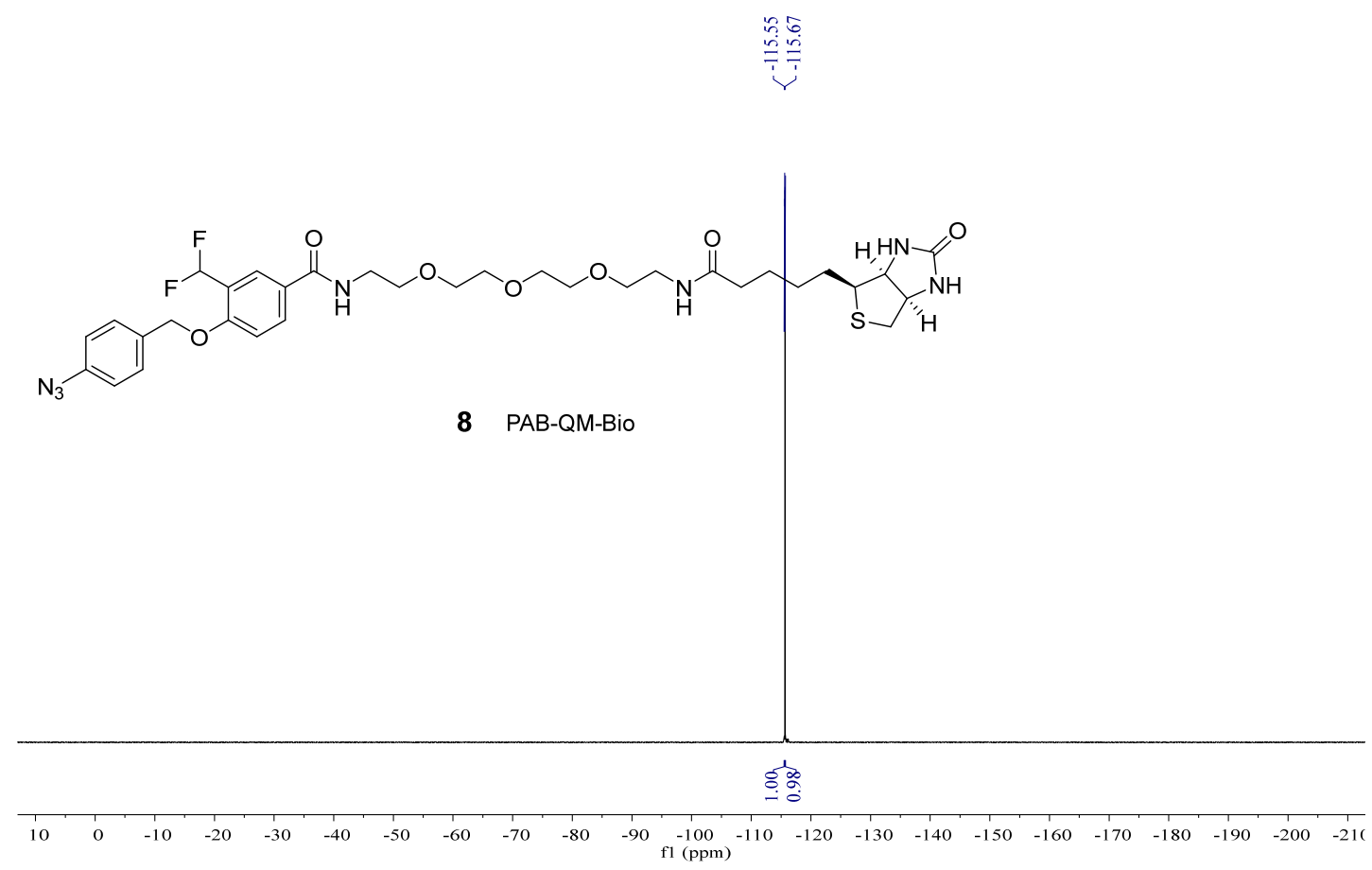

10: ${ }^{1} \mathrm{H}$ NMR (400 MHz, Chloroform- $d$ )

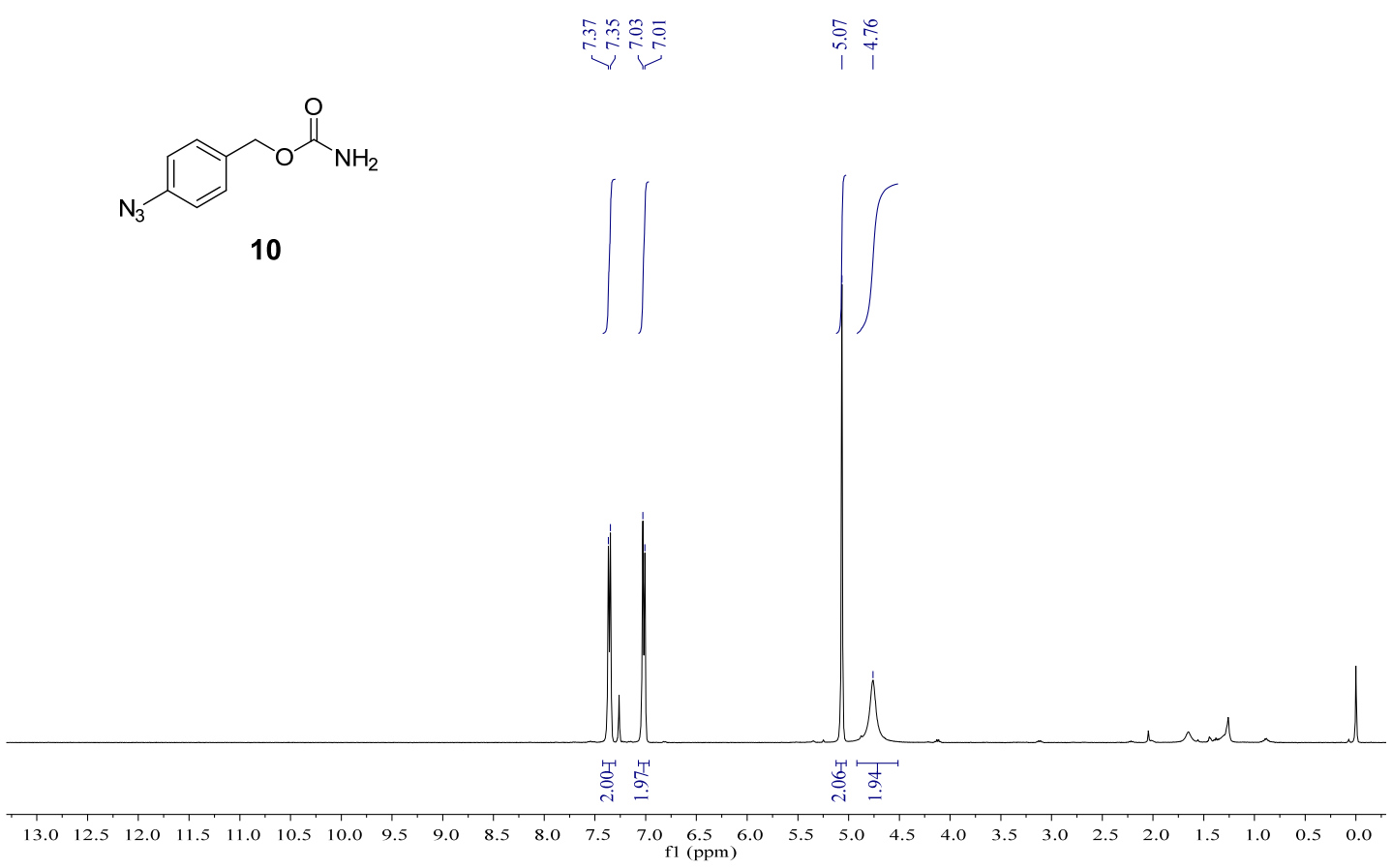


10: ${ }^{13} \mathrm{C}$ NMR (101 MHz, Chloroform- $d$ )

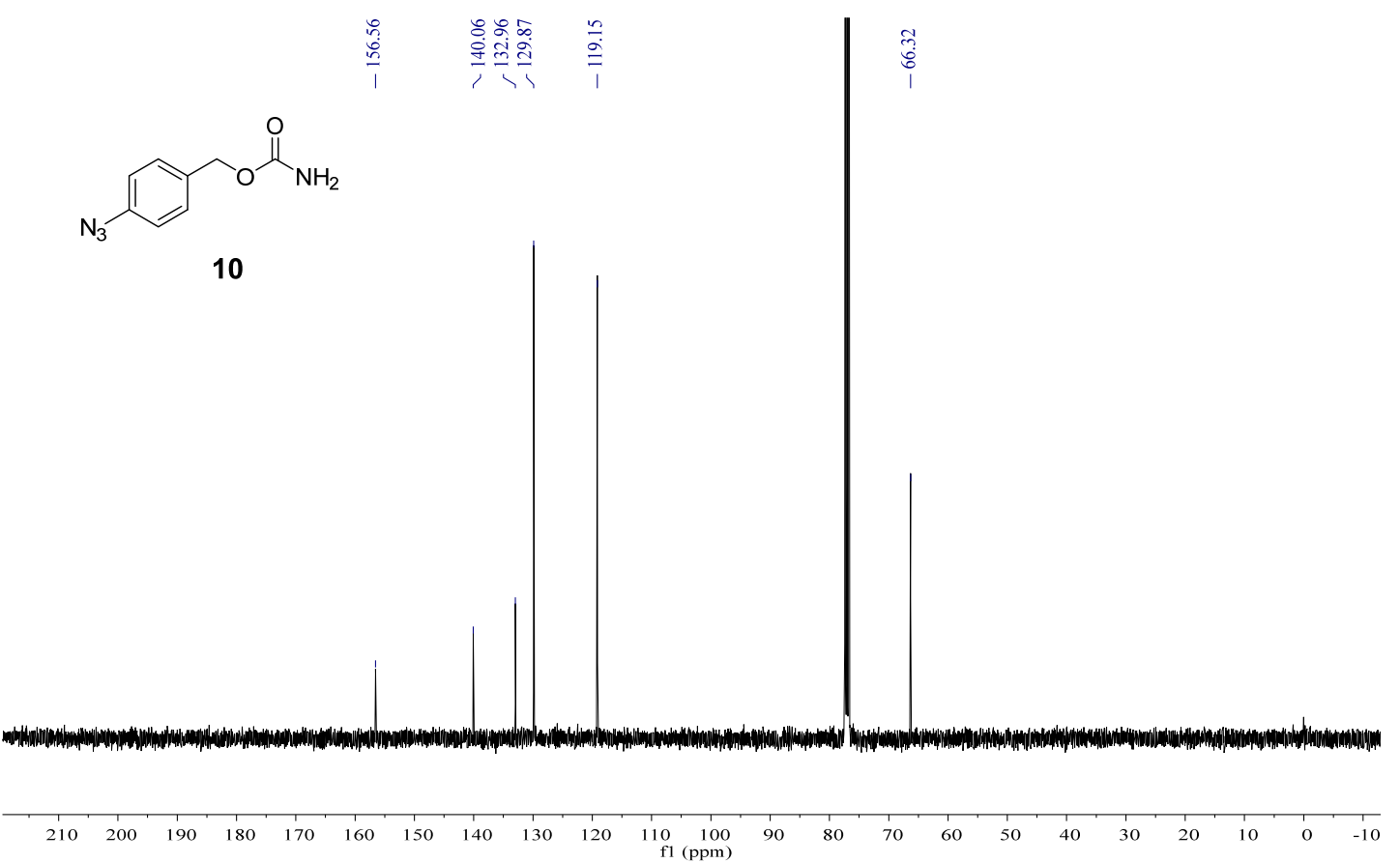

11: ${ }^{1} \mathrm{H}$ NMR (400 MHz, Chloroform- $d$ )

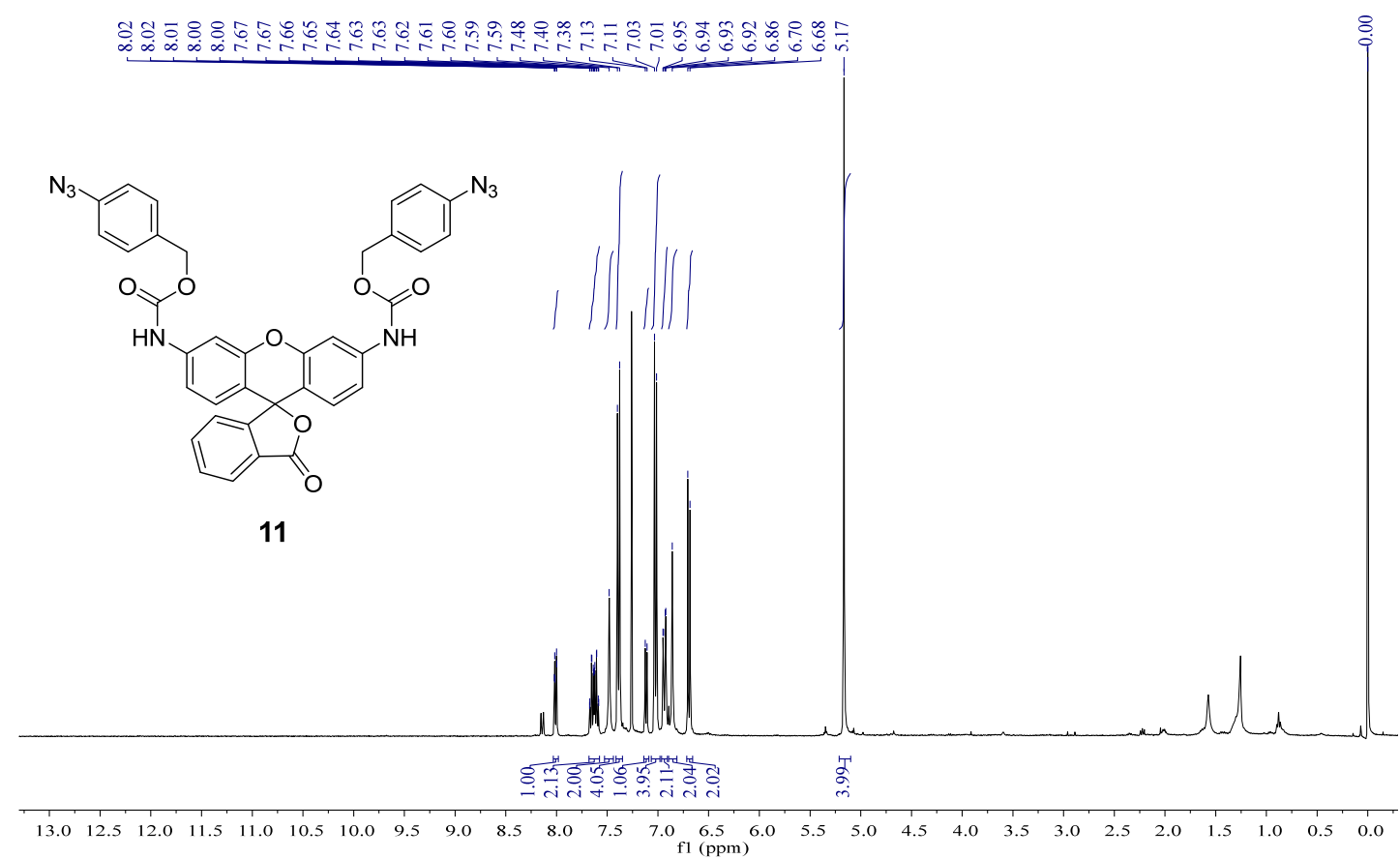


11: ${ }^{13} \mathrm{C}$ NMR (101 MHz, Chloroform- $d$ )
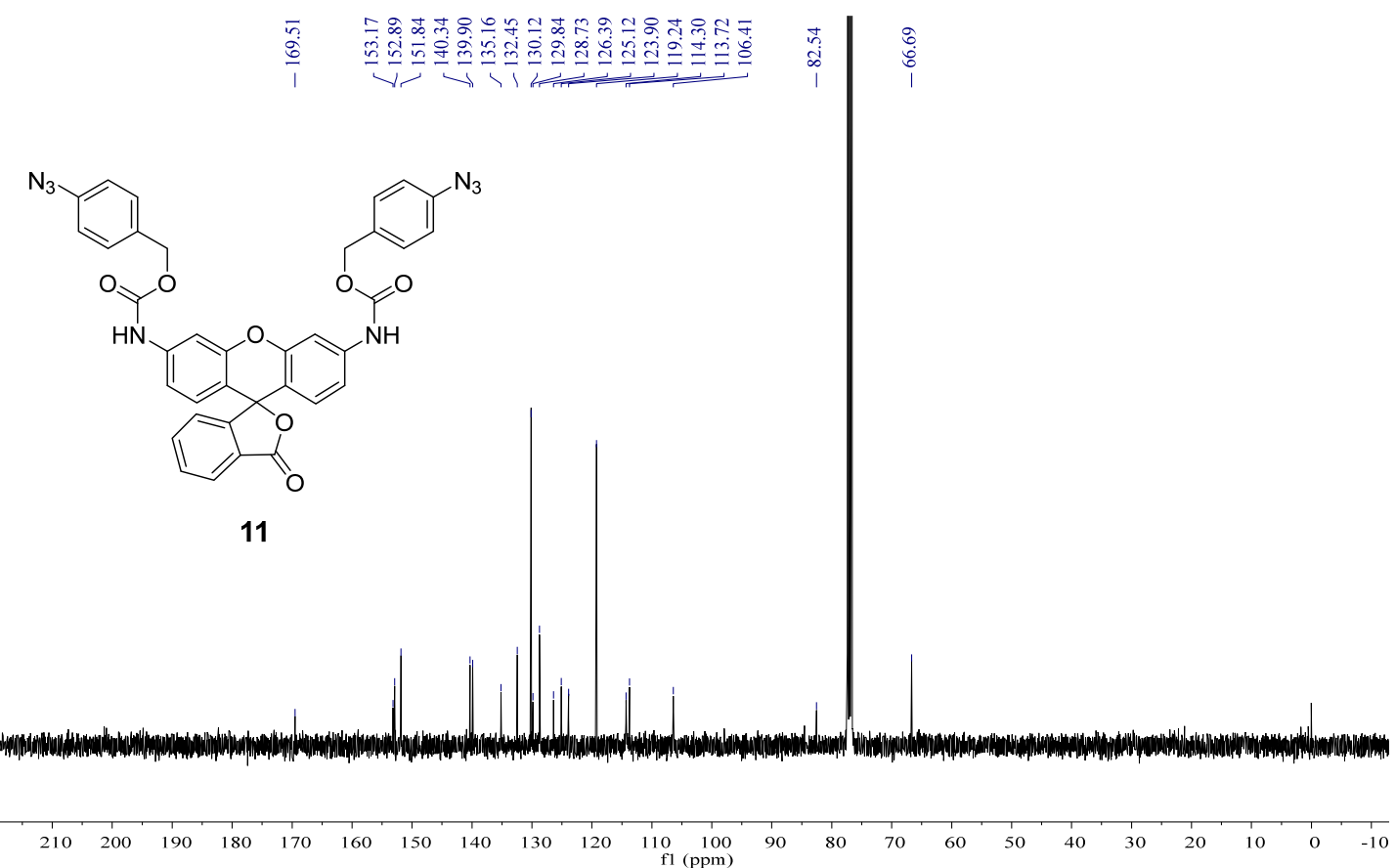